\title{
Progress Towards Bioelectrochemical Remediation of Hexavalent Chromium
}

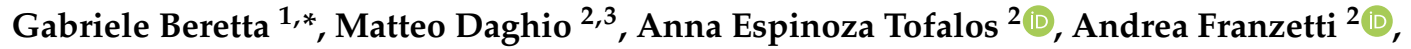 \\ Andrea Filippo Mastorgio ${ }^{1}$ (D), Sabrina Saponaro ${ }^{1}$ (D) and Elena Sezenna ${ }^{1, *(D)}$ \\ 1 Department of Civil and Environmental Engineering, Politecnico di Milano, Piazza Leonardo da Vinci 32, \\ 20133 Milano, Italy; andreafilippo.mastorgio@polimi.it (A.F.M.); sabrina.saponaro@polimi.it (S.S.) \\ 2 Department of Earth and Environmental Sciences, University of Milano-Bicocca, Piazza della Scienza 1, \\ 20126 Milano, Italy; matteo.daghio@unimib.it (M.D.); anna.espinoza@unimib.it (A.E.T.); \\ andrea.franzetti@unimib.it (A.F.) \\ 3 Department of Agriculture, Food, Environment and Forestry, University of Florence, Piazzale delle Cascine \\ 18, 50144 Firenze, Italy \\ * Correspondence: gabriele.beretta@polimi.it (G.B.); elena.sezenna@polimi.it (E.S.); Tel.: +39-02-239-964-32
}

Received: 1 October 2019; Accepted: 3 November 2019; Published: 7 November 2019

\begin{abstract}
Chromium is one of the most frequently used metal contaminants. Its hexavalent form $\mathrm{Cr}(\mathrm{VI})$, which is exploited in many industrial activities, is highly toxic, is water-soluble in the full $\mathrm{pH}$ range, and is a major threat to groundwater resources. Alongside traditional approaches to $\mathrm{Cr}(\mathrm{VI})$ treatment based on physical-chemical methods, technologies exploiting the ability of several microorganisms to reduce toxic and mobile $\mathrm{Cr}(\mathrm{VI})$ to the less toxic and stable $\mathrm{Cr}(\mathrm{III})$ form have been developed to improve the cost-effectiveness and sustainability of remediating hexavalent chromium-contaminated groundwater. Bioelectrochemical systems (BESs), principally investigated for wastewater treatment, may represent an innovative option for groundwater remediation. By using electrodes as virtually inexhaustible electron donors and acceptors to promote microbial oxidation-reduction reactions, in in situ remediation, BESs may offer the advantage of limited energy and chemicals requirements in comparison to other bioremediation technologies, which rely on external supplies of limiting inorganic nutrients and electron acceptors or donors to ensure proper conditions for microbial activity. Electron transfer is continuously promoted/controlled in terms of current or voltage application between the electrodes, close to which electrochemically active microorganisms are located. Therefore, this enhances the options of process real-time monitoring and control, which are often limited in in situ treatment schemes. This paper reviews research with BESs for treating chromium-contaminated wastewater, by focusing on the perspectives for $\mathrm{Cr}(\mathrm{VI})$ bioelectrochemical remediation and open research issues.
\end{abstract}

Keywords: bioelectrochemical systems (BESs); hexavalent chromium; electrobioremediation; groundwater treatment

\section{Introduction}

Hexavalent $\mathrm{Cr}(\mathrm{VI})$ and trivalent $\mathrm{Cr}(\mathrm{III})$ chromium are the most common forms of this element in the environment. $\mathrm{Cr}(\mathrm{VI})$ is water-soluble in the full $\mathrm{pH}$ range and extremely toxic to human health and all living organisms because of its mutagenic and carcinogenic properties [1]. The U.S. EPA has classified $\mathrm{Cr}(\mathrm{VI})$ as one of the 17 most dangerous elements for human health [2,3]. In aqueous systems, $\mathrm{Cr}(\mathrm{VI})$ can be present in different species: primarily as chromic acid $\left[\mathrm{H}_{2} \mathrm{CrO}_{4}\right]$ and its salts, the hydrogen chromate ion $\left[\left(\mathrm{HCrO}_{4}\right)^{-}\right]$, and the chromate ion $\left[\left(\mathrm{CrO}_{4}\right)^{2-}\right]$. The chemical equilibrium of the different chromium species depends on $\mathrm{Cr}(\mathrm{VI})$ concentration, oxidation-reduction potential (ORP), 
and $\mathrm{pH}$ of the system [3]. $\mathrm{Cr}(\mathrm{III})$ is less toxic and more stable than $\mathrm{Cr}(\mathrm{VI})$ in aquatic environments, since under natural conditions, at moderately acidic or alkaline $\mathrm{pH}$, it tends to precipitate as chromium hydroxide or oxide $\left(\mathrm{Cr}(\mathrm{OH})_{3}\right.$ or $\left.\mathrm{Cr}_{2} \mathrm{O}_{3}\right)[4,5]$.

Hexavalent chromium has been, and it is still used, in many industrial activities such as chromite ore processing, electroplating, in the production of dyes and pigments, pharmaceuticals, in leather tanning, in wood preservation/processing, and in the metallurgical industry for alloy preparation [6-8]. Improper management of $\mathrm{Cr}(\mathrm{VI})$-containing effluents or wastes led to widespread chromium environmental contamination around the world. As a consequence of its subsequent mobility in water, groundwater resources are especially vulnerable to $\mathrm{Cr}(\mathrm{VI})$ contamination, with levels often shown to exceed the internationally acceptable exposure limit in water of $0.05 \mathrm{mg} \mathrm{Cr}(\mathrm{VI}) / \mathrm{L}[9,10]$.

Hexavalent chromium in industrial wastewater is typically treated by reduction, and subsequent precipitation, to the non-toxic $\mathrm{Cr}$ (III) by means of reductants (for instance, $\mathrm{FeSO}_{4}, \mathrm{Na}_{2} \mathrm{~S}_{2} \mathrm{O}_{5}$, and $\mathrm{SO}_{2}$ ) [11] or electrochemical processes (including electrocoagulation, electro-reduction, electrodialysis, and electro-deionization) [12]. Generally, these processes are easy to implement and efficient at high or moderate $\mathrm{Cr}(\mathrm{VI})$ concentrations. However, the use of reductants produces a large amount of metallic sludge, and both the above-mentioned approaches are either ineffective or not cost-effective when applied for trace $\mathrm{Cr}(\mathrm{VI})$ treatment. Adsorption on adsorbents, such as activated carbons or zeolites, is also adopted, since this process exhibits several advantages of simple operation, low cost, and high efficiency $[13,14]$. Nevertheless, this strategy presents some disadvantages such as needing regeneration of adsorption media and no degradation/detoxification of $\mathrm{Cr}(\mathrm{VI})$ to $\mathrm{Cr}(\mathrm{III})$ is achieved [15].

Conventional methods for $\mathrm{Cr}(\mathrm{VI})$ contaminated site remediation, soil excavation, and groundwater pump and treat (P\&T), despite still being widely applied, are energy and chemical-intensive and entail high costs [16]. Furthermore, the P\&T method, which involves the extraction of contaminated water from the aquifer and above-ground treatment, tends to be poorly efficient when dealing with contaminated plumes at relatively low $\mathrm{Cr}(\mathrm{VI})$ concentrations [17].

In situ chemical strategies are applied using $\mathrm{Fe}(0)$ permeable reactive barriers or by injecting nano- $\mathrm{Fe}(0), \mathrm{Na}_{2} \mathrm{~S}_{2} \mathrm{O}_{4}$ or hydrogen sulphide to develop reactive zones in the aquifer $[7,18,19]$. The applicability and effectiveness of these approaches are limited by high costs, poor chemical distributions, and undesired side reactions in the subsurface [20].

Recent studies have shown that microbial activity can indirectly promote $\mathrm{Cr}(\mathrm{VI})$ reduction and immobilization in contaminated groundwater and/or soil. Bio-reduction relies on injections of biodegradable organic substrates (e.g., molasses), whose rapid microbial degradation by indigenous heterotrophic microorganisms prompts anaerobic conditions in the subsurface and produces reductants, such as $\mathrm{S}^{2-}, \mathrm{Fe}(\mathrm{II})$, and fermentation metabolites, which are able to mediate $\mathrm{Cr}(\mathrm{VI})$ chemical reduction and precipitation [21-24].

Selected microorganisms can directly bio-reduce $[25,26]$ and bio-sorb [27] $\mathrm{Cr}(\mathrm{VI})$ as well. Nevertheless, the presence of suitable microorganisms in conjunction with favorable environmental conditions is essential. The performance of in situ $\mathrm{Cr}(\mathrm{VI})$ bio-remediation, by relying on either induced—or direct—bioreduction/biosorption mechanisms, is, therefore, influenced by the abundance of suitable electron acceptors and donors, carbon sources, and nutrients for the microorganisms, which often require external supplements for a balance [20]. The control of supply rates can be a crucial step to avoid unwanted side reactions and the accumulation of undesired substances (e.g., excess substrates or nutrients, fermentation products) that contribute to the deterioration of soil and water quality.

$\mathrm{Cr}(\mathrm{VI})$, like any metal, is not actually removed by in situ remediation, but only changes its form and valence. This requires careful evaluation of the long-term stability of reduced products, post-treatment, and of possible re-oxidation mechanisms [28,29]. $\mathrm{Cr}$ (III) in the precipitates formed during remediation, whether exposed to environmentally common Mn oxides, such as the birnessite, have the potential of rapid re-oxidation to $\mathrm{Cr}(\mathrm{VI})$. Even highly oxidized $\mathrm{Mn}(\mathrm{III}, \mathrm{IV})$ oxides are likely unstable under reducing conditions, in case these are caused by the addition of electron donors as part 
of the $\mathrm{Cr}(\mathrm{VI})$ remediation strategy. $\mathrm{Cr}$ could be re-mobilized when the donor addition stops and the site returns to natural oxidizing conditions [28].

A promising strategy to be explored for in situ $\mathrm{Cr}(\mathrm{VI})$ bioremediation is the application of bioelectrochemical systems (BESs), which is an emerging platform technology combining microbial processes with electrochemical systems. In BESs, the ability of electrochemically active microorganisms (EAM) to use electrodes as inexhaustible electron acceptors/donors are exploited, via a process typically referred to as extracellular electron transfer [30-32]. BES reactors essentially consist of electrodes, an anode and a cathode, immersed in an electrolytic medium/solution and an optional ion-exchange membrane to separate the compartments. At the anode, oxidation of reduced species generates a flow of electrons to the cathode, where reduction reactions take place. At least one or both reactions are microbially mediated. Membranes provide a separation structure to isolate different bulk liquids in the anode and cathode chambers, to optimize the operating condition without affecting the microbial community, to prevent undesired substrate transport, and to facilitate transfer of ionic species from one chamber to another for charge balance, increasing, however, the internal resistance of the system [33]. In case of thermodynamically favorable redox reactions, BESs can result in direct electricity production (microbial fuel cells, MFCs) $[30,34,35]$ or, by external energy supply, in enhancement of thermodynamically unfavorable processes [36], with production of less toxic or value-added chemicals (such as hydrogen, $\mathrm{H}_{2} \mathrm{O}_{2}$, methane, or even organic molecules) (in microbial electrolysis cells, MECs) [37].

BESs have been extensively studied and intensively developed, especially during the last 10 years, for wastewater treatment, valorization, and reuse [38,39]. In environmental remediation, BESs, through biologically-mediated oxidation (at the anode) and reduction (at the cathode), potentially provide a flexible platform for treating many pollutants frequently found at contaminated sites, in co-contamination cases $[40,41]$. Solid electrodes can serve, in fact, either as an electron sink, for the oxidation of petroleum hydrocarbons [42-44] or As(III) [45], or as electron donor, for reduction of chlorinated hydrocarbons [46,47], nitrate [48], or oxidized metals, including $\mathrm{Cr}(\mathrm{VI})$ [49].

In in situ treatments, it would be possible to directly introduce the electrodes in the aquifer and stimulate biologic activity with no external chemicals or a minimal external chemical supply [50], which creates an advantage in terms of cost-effectiveness and sustainability in comparison to current approaches [51]. The electrical signal generated in BESs provides opportunities for real-time monitoring of $\mathrm{Cr}(\mathrm{VI})$ concentration [52-54] and in situ microbial activity [55]. $\mathrm{Cr}$ (III) deposition next to the electrode theoretically offers the chance of recovering the metal itself through the electrode [39].

Several experimental works investigated $\mathrm{Cr}(\mathrm{VI})$ reduction in MFCs with bioanodes and either abiotic cathodes, relying on $\mathrm{Cr}(\mathrm{VI})$ electrochemical reduction, or biocathodes, while taking advantage of biological activity. However, no research, to our knowledge, has yet specifically addressed $\mathrm{Cr}(\mathrm{VI})$ contaminated groundwater remediation. This review provides a comprehensive analysis of the current knowledge and experiences in bio-electrochemical treatment of $\mathrm{Cr}(\mathrm{VI})$ contaminated water streams, in order to explore BESs opportunities for in situ groundwater bioremediation.

\section{Principles of $\mathrm{Cr}(\mathrm{VI})$ Reduction in Bio-Electrochemical Systems}

Bio-electrochemical $\mathrm{Cr}(\mathrm{VI})$ reduction essentially relies on cathodic reduction (Figure 1), with most research focused on wastewater treatment coupled with energy recovery in MFCs, with biotic anodes and either abiotic or biotic cathodes [56]. Only a single study evaluated $\mathrm{Cr}(\mathrm{VI})$ detoxification at the bioanode, via bacterial protection mechanisms [57]. 


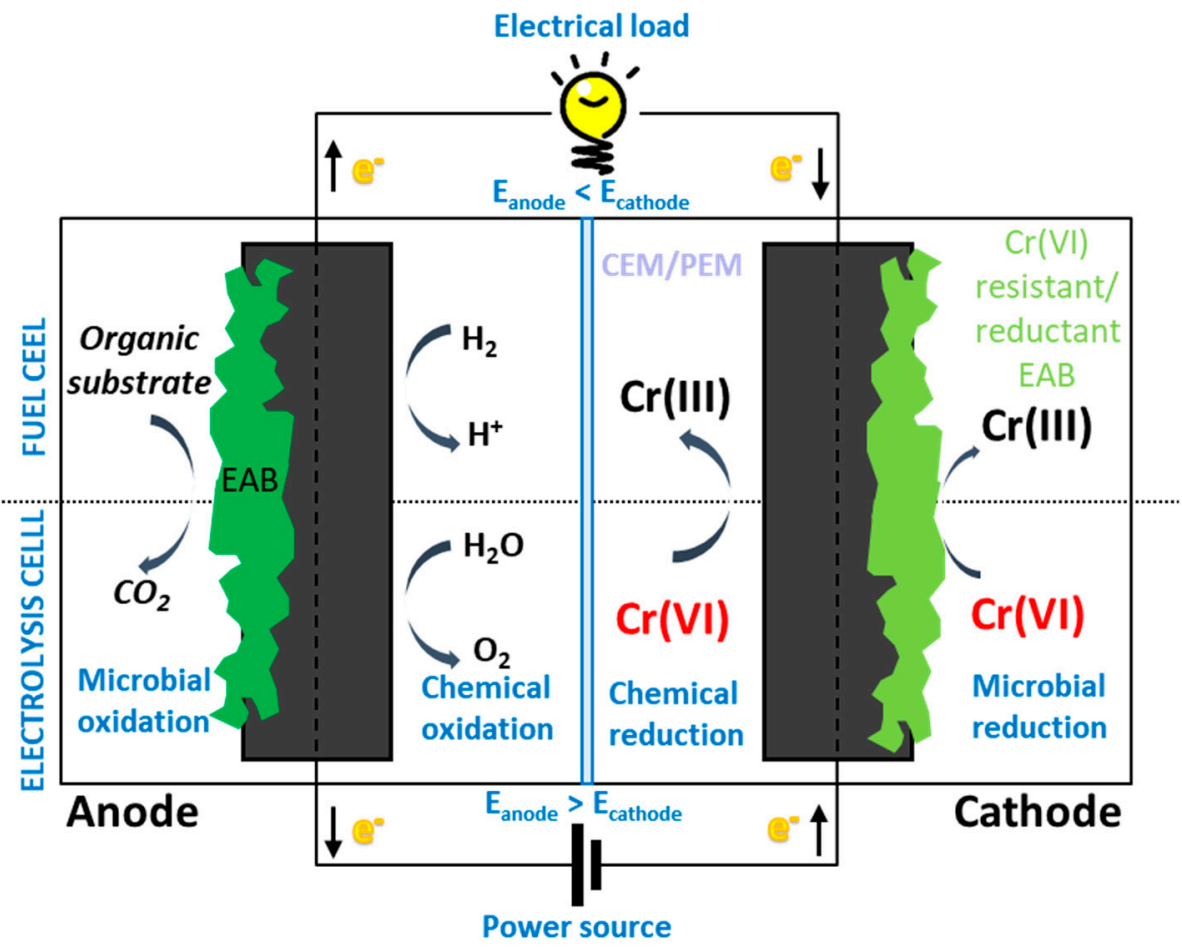

Figure 1. Schematic overview of a BES for $\mathrm{Cr}(\mathrm{VI})$ reduction as MFC with energy harvesting or MEC with external supply ([58], modified). In MFCs, oxidation of the electron donor at the anode is coupled with a reduction of species with comparable or higher redox potential at the cathode. The net potential of the MFC, as the sum of anodic and cathodic potentials, is positive. Therefore, spontaneous electron flow from the anode to the cathode occurs. Conversely, in MEC, thanks to external power input to force electron flow, the oxidation of an electron donor at the anode can be coupled with the reduction of lower redox potential species at the cathode. CEM/PEM: Cation/Proton Exchange Membrane. EAB: Electrochemically Active Bacteria

\subsection{Electrochemical Reduction of $\mathrm{Cr}(V I)$}

Due to its high standard reduction potential, which is comparable, or, in certain conditions, even higher than those of other commonly used electron acceptors in BESs, $\mathrm{Cr}(\mathrm{VI})$ has been initially investigated as a theoretically favorable electron acceptor, to get reduced at abiotic cathodes in a typical MFC configuration for power production. This concept has been demonstrated for the first time in a dual-chamber MFC (2CMFC) by Wang et al. [59] who, using acetate as electron donor and Cr(VI) solution at a $\mathrm{pH}$ of 2 as acceptor, observed higher power densities than for $\mathrm{O}_{2}$ and hexacyanoferrate.

The half-cell $\mathrm{Cr}(\mathrm{VI})$ reduction potential and the stoichiometry of the reaction are, however, strongly dependent on chromium species, concentration, and $\mathrm{pH}$ conditions (Table 1).

In water solutions, the dichromate $\mathrm{Cr}_{2} \mathrm{O}_{7}{ }^{2-}$ form prevails for total chromium concentrations above approximately $1 \mathrm{~g} / \mathrm{L}[3,17]$. At lower concentrations, which typically occurs in groundwater plumes or natural surface water, the dominant species is $\mathrm{HCrO}_{4}{ }^{-}$at a $\mathrm{pH}$ between 1 and about 6 to 6.5, and $\mathrm{CrO}_{4}{ }^{2-}$ at neutral or alkaline conditions [60]. High positive standard reduction potentials ( $\mathrm{Eh}^{0}$ vs. SHE) for both $\mathrm{Cr}_{2} \mathrm{O}_{7}{ }^{2-}$ and $\mathrm{HCrO}_{4}{ }^{-}$indicate a thermodynamically favorable reaction, conducive to high power density generation in BESs, only in acidic environments $[39,59,61]$. On the contrary, $\mathrm{CrO}_{4}{ }^{2-}$ lower potential limits chromium electrochemical reduction in the neutral $\mathrm{pH}$ range, which often makes the external energy supply necessary. Furthermore, at $\mathrm{pH}<4$, the predominant form of chromium reduction is dissolved $\mathrm{Cr}^{3+}$, whereas in the $5-8 \mathrm{pH}$ range, soluble $\mathrm{Cr}(\mathrm{OH})_{2}{ }^{+}$and $\mathrm{Cr}(\mathrm{OH})^{2+}$, coexist with $\mathrm{Cr}(\mathrm{OH})_{3}$ or $\mathrm{Cr}_{2} \mathrm{O}_{3}$ precipitates, which are responsible for the progressive deterioration of the reduction rates as $\mathrm{Cr}(\mathrm{III})$ deposits onto the cathode surface, especially at a $\mathrm{pH}$ above 6.5 [62,63]. 
Table 1. Standard potentials $\left(\mathrm{E}_{\mathrm{h}}{ }^{0}\right)$ at $25^{\circ} \mathrm{C}$ (V vs. Standard Hydrogen Electrode, SHE) and theoretical potential $\left(\mathrm{E}_{\mathrm{h}}{ }^{\prime}\right)$ at $\mathrm{pH}=7$ and $25^{\circ} \mathrm{C}(\mathrm{V}$ vs. SHE) of $\mathrm{Cr}(\mathrm{VI})$ and other selected species of interest for BESs application in $\mathrm{Cr}(\mathrm{VI})$ groundwater remediation, sourced from $[32,39,59]$.

\begin{tabular}{ccc}
\hline Reaction & $\mathbf{E}_{\mathbf{h}}{ }^{0}$ (V vs. SHE) & $\mathbf{E}_{\mathbf{h}^{\prime}}$ at $\mathbf{p H}$ (V vs. SHE) \\
\hline $\mathrm{Cr}_{2} \mathrm{O}_{7}{ }^{2-}+14 \mathrm{H}^{+}+6 \mathrm{e}^{-} \rightarrow 2 \mathrm{Cr}^{3+}+7 \mathrm{H}_{2} \mathrm{O}$ & 1.33 & 0.33 \\
$\mathrm{HCrO}_{4}-+7 \mathrm{H}^{+}+3 \mathrm{e}^{-} \rightarrow \mathrm{Cr}^{3+}+4 \mathrm{H}_{2} \mathrm{O}$ & 1.35 & 0.35 \\
$\mathrm{HCrO}_{4}-+4 \mathrm{H}^{+}+3 \mathrm{e}^{-} \rightarrow \mathrm{Cr}(\mathrm{OH})_{2}{ }^{+}+3 \mathrm{H}_{2} \mathrm{O}$ & 1.31 & 0.76 \\
$\mathrm{CrO}_{4}{ }^{2-}+4 \mathrm{H}_{2} \mathrm{O}+3 \mathrm{e}^{-} \rightarrow \mathrm{Cr}(\mathrm{OH})_{3(\mathrm{~s}, \text { hydrated })+5 \mathrm{OH}^{-}}$ & -0.13 & 0.21 \\
$\mathrm{O}_{2}+4 \mathrm{H}^{+}+4 \mathrm{e}^{-} \rightarrow \mathrm{H}_{2} \mathrm{O}$ & 1.23 & $0.805\left(\mathrm{pO}_{2}=0.2 \mathrm{bar}\right)$ \\
$\mathrm{NO}_{3}{ }^{-}+6 \mathrm{H}^{+}+5 \mathrm{e}^{-} \rightarrow 1 / 2 \mathrm{~N}_{2}+3 \mathrm{H}_{2} \mathrm{O}$ & 1.24 & $0.71\left(\mathrm{pN}_{2}=0.8\right.$ bar $)$ \\
$\mathrm{Fe}^{3+}+\mathrm{e}^{-} \rightarrow \mathrm{Fe}^{2+}$ & 0.77 & 0.77 \\
$\mathrm{SO}_{4}{ }^{2-}+10 \mathrm{H}^{+}+8 \mathrm{e}^{-} \rightarrow \mathrm{H}_{2} \mathrm{~S}+4 \mathrm{H}_{2} \mathrm{O}$ & 0.30 & -0.21 \\
$\mathrm{HCO}_{3}{ }^{-}+9 \mathrm{H}_{+}+8 \mathrm{e}^{-} \rightarrow \mathrm{CH}_{4}(\mathrm{~g})+3 \mathrm{H}_{2} \mathrm{O}$ & 0.20 & -0.26 \\
$2 \mathrm{HCO}_{3}{ }^{-}+9 \mathrm{H}^{+}+8 \mathrm{e}^{-} \rightarrow \mathrm{CH}_{3} \mathrm{COO}^{-}+4 \mathrm{H}_{2} \mathrm{O}$ & 0.19 & -0.29 \\
$2 \mathrm{H}^{+}+2 \mathrm{e}^{-} \rightarrow \mathrm{H}_{2(\mathrm{~g})}$ & 0 & $-0.41\left(\mathrm{pH} \mathrm{H}_{2}=1\right.$ bar $)$ \\
$\mathrm{MnO}_{2(\mathrm{~s})}+4 \mathrm{H}^{+}+2 \mathrm{e}^{-} \rightarrow \mathrm{Mn}^{2+}+2 \mathrm{H}_{2} \mathrm{O}$ & 1.23 & 0.402 \\
\hline
\end{tabular}

Effective abiotic electrochemical reduction requires strongly acidic conditions (optimally at a $\mathrm{pH}$ of 2) that greatly limit its applicability to environmental remediation.

Biologically mediated $\mathrm{Cr}(\mathrm{VI})$ reduction, relying on several microbiological mechanisms, may overcome the current issues of abiotic electrochemical reduction, by offering opportunities to hexavalent chromium treatment in the environmentally compatible neutral $\mathrm{pH}$ range. Moreover, the biofilm on the cathode may somewhat protect and improve the long-term efficiency of the electrode by preventing or delaying $\mathrm{Cr}(\mathrm{III})$ deposition $[64,65]$.

\subsection{Microbiological Mechanisms of $\mathrm{Cr}(\mathrm{VI})$ Reduction}

Several mechanisms of bacterial $\mathrm{Cr}(\mathrm{VI})$ reduction have been described both under aerobic and anaerobic conditions $[66,67]$.

In the presence of oxygen, the reduction of $\mathrm{Cr}(\mathrm{VI})$ is commonly associated with soluble chromate reductases and requires reduced nicotinamide-adenine dinucleotide phosphate $(\mathrm{NAD}(\mathrm{P}) \mathrm{H})$ as electron donor $[66,68]$. The mechanisms associated with $\mathrm{Cr}(\mathrm{VI})$ reduction can involve a direct, one-step or two-step electron transfer. Escherichia coli YieF $\mathrm{Cr}(\mathrm{VI})$ reductase transfers three electrons to $\mathrm{Cr}(\mathrm{VI})$ in one step to produce $\mathrm{Cr}(\mathrm{III})$, and one to molecular oxygen generating reactive oxygen species (ROS) [69]. The $\mathrm{Cr}(\mathrm{VI})$ reductase ChrR from Pseudomonas putida involves a one/two steps mechanism in which one/two electrons are donated from $\mathrm{NAD}(\mathrm{P}) \mathrm{H}$ to generate the intermediate $\mathrm{Cr}(\mathrm{V}) / \mathrm{Cr}(\mathrm{IV})$ that is further reduced to $\mathrm{Cr}$ (III) by one/two additional electrons [66,70]. Under aerobic conditions, most $\mathrm{Cr}(\mathrm{VI})$-resistant microorganisms tolerate up to $1500 \mathrm{mg} \mathrm{Cr}(\mathrm{VI}) / \mathrm{L}$ [71]. However, the rate of chromium reduction is directly related to the concentration of the contaminant and physical parameters, such as $\mathrm{pH}$ and temperature [71,72]. One of the first studies with $\mathrm{Cr}(\mathrm{VI})$-reducing bacteria, achieved almost $100 \%$ of chromate reduction in $2.0 \mathrm{mg} / \mathrm{L} \mathrm{Cr}(\mathrm{VI})$ solution within $90 \mathrm{~h}$ by P. putida PRS2000 and P. fluorescens LB303 [73]. Similar results were obtained by the soil-isolated strains Bacillus sp. E29 and Arthrobacter crystallopoietes strain ES32 that achieved reductions of $82 \%$ and $90 \%$ of $\mathrm{Cr}(\mathrm{VI})$ in less than $6 \mathrm{~h}$ and $12 \mathrm{~h}$, respectively [71]. Much higher $\mathrm{Cr}(\mathrm{VI})$ concentrations were removed by Serratia proteamaculans. Within $48 \mathrm{~h}, 100 \mathrm{mg} \mathrm{Cr}(\mathrm{VI}) / \mathrm{L}$ were reduced (corresponding to 100\% of dichromate added) under aerobic conditions [72]. In the same study, the authors demonstrated that $S$. proteamaculans was also able to reduce chromate anaerobically, but the process was more efficient in the presence of oxygen.

Chromium-resistant microorganisms have also been found in marine environments. A $\mathrm{Cr}(\mathrm{VI})$-resistant bacterium isolated from seawater and identified as Exiguobacterium indicum achieved nearly $92 \%, 50 \%$, and $46 \%$ reduction for 100, 500, and $1000 \mathrm{mg} \mathrm{Cr}(\mathrm{VI}) / \mathrm{L}$, respectively, after $192 \mathrm{~h}$ of incubation [74].

Under anaerobic conditions, $\mathrm{Cr}(\mathrm{VI})$ can serve as the final electron acceptor in a process that usually involves membrane-bound reductases [66], but also soluble enzymes (e.g., soluble cytochrome $c_{3}$ 
from Desulfovibrio vulgaris) were observed to reduce $\mathrm{Cr}(\mathrm{VI})$ [75]. The overall reaction is provided in Equation (1), with glucose as electron donor [76].

$$
\mathrm{C}_{6} \mathrm{H}_{12} \mathrm{O}_{6}+8 \mathrm{CrO}_{4}{ }^{2-}{ }_{(\mathrm{aq})}+14 \mathrm{H}_{2} \mathrm{O} \rightarrow 8 \mathrm{Cr}(\mathrm{OH})_{3(\mathrm{~s})}+10 \mathrm{OH}^{-}{ }_{(\mathrm{aq})}+6 \mathrm{HCO}^{-}{ }_{(\mathrm{aq})}
$$

$\mathrm{Cr}(\mathrm{VI})$ reduction in anaerobic conditions was reported in several microorganisms. Both $P$. dechromaticans and in Enterobacter cloacae are capable to use $\mathrm{Cr}(\mathrm{VI})$ as terminal electron acceptor [66,77]. Gene expression of Shewanella oneidensis MR-1 during $\mathrm{Cr}(\mathrm{VI})$ reduction was studied [78]. Under $\mathrm{Cr}(\mathrm{VI})$ reducing conditions, 83 genes were upregulated. Among the others, genes involved in the reduction of $\mathrm{Fe}(\mathrm{III})$ and $\mathrm{Mn}(\mathrm{IV})$ were also upregulated. Further studies with mutant strains confirmed the involvement of $m \operatorname{tr} A, m t r B, m t r C$, and $o m c A$ in the reduction of $\mathrm{Cr}(\mathrm{VI})[78,79]$.

In anaerobic environments, iron(II) and sulphide can also play a role in $\mathrm{Cr}(\mathrm{VI})$ reduction $[66,80]$. Iron-reducing bacteria (IRB) reduce $\mathrm{Fe}(\mathrm{III})$ to $\mathrm{Fe}(\mathrm{II})$, and biologically produced $\mathrm{Fe}(\mathrm{II})$ can be re-oxidized by reducing $\mathrm{Cr}(\mathrm{VI})$ to $\mathrm{Cr}(\mathrm{III})$ [76]. Sulphate is an electron acceptor widely used by several bacterial groups for the degradation of the organic matter in anaerobic environments [81]. In sulphate-rich environments, $\mathrm{Cr}(\mathrm{VI})$ can react with sulphide produced by sulphate-reducing bacteria (SRB) to produce $\mathrm{Cr}(\mathrm{III})$ that precipitates [76].

In addition to laboratory studies focused on the elucidation of possible mechanisms used by bacteria for $\mathrm{Cr}(\mathrm{VI})$ reduction, the ability to reduce $\mathrm{Cr}(\mathrm{VI})$ in soil-aquifer systems has been reported but needs to be further investigated. Clostridium chromiireducens sp. a $\mathrm{Cr}(\mathrm{VI})$-resistant, Gram-positive, spore-forming, obligate anaerobe, was identified for its ability to reduce $\mathrm{Cr}(\mathrm{VI})$ at a contaminated site [82]. Many previous reports also confirmed autotrophic reduction of chromium, by mostly using hydrogen as electron donor [83,84]. A Gram-negative bacterium, capable of reducing hexavalent chromium, was also isolated from a contaminated site. 16S rRNA analysis revealed that it belonged to the Pseudomonas genus, with high similarity to P. synxantha [85,86]. Marsh and McInerney [2] demonstrated reduction of $\mathrm{Cr}(\mathrm{VI})$ with hydrogen and carbon dioxide/ $/ \mathrm{NaHCO}_{3}$ as an electron donor and carbon source, respectively, carried out by an anaerobic mixed culture developed from aquifer sediment.

As previously reported, the reduction of the $\mathrm{Cr}(\mathrm{VI})$ can occur through the action of soluble cytochromes [66], membrane reductase mtrCAB, and omcA [78,79]. Kracke and colleagues [87] report that the mtrCAB terminal reductase complex and the omcA cytochrome are able to interact with the electrode directly or via mediators (flavins). This scientific evidence combined with the well documented ability of IRB (i.e., Shewanella oneidensis MR-1) [78] and SRB (i.e., Desulfovibrio desulfuricans 27774) [88] to reduce $\mathrm{Cr}(\mathrm{VI})$ and to exchange electrons with solid materials are good reasons to consider the feasibility of a bio-electrochemical system for reducing $\mathrm{Cr}(\mathrm{VI})$.

All the previously described biological mechanisms can take place in BESs. The inoculated cathode may act as an electron donor for electrochemical or bio-electrochemical $\mathrm{Cr}(\mathrm{VI})$ reduction. Electroactive Cr-reducing microorganisms in the cathodic biofilm or the production of hydrogen at the cathode of a BES could also favor the autotrophic reduction of $\mathrm{Cr}(\mathrm{VI})$ by hydrogenotrophic bacteria $[2,83,84]$, or IRB or SRB involved in bio-electrochemical processes may facilitate indirect reduction of $\mathrm{Cr}(\mathrm{VI})$.

\section{Cr(VI) Biocathodic Reduction}

Table 2 summarizes the available research experiences of $\mathrm{Cr}(\mathrm{VI})$ reduction with biocathodes, by focusing on the electrode materials and inoculum, cathode potential, $\mathrm{pH}, \mathrm{Cr}(\mathrm{VI})$ concentrations, the observed $\mathrm{Cr}(\mathrm{VI})$ removal rates, and efficiencies. 
Table 2. Summary of key studies regarding $\mathrm{Cr}(\mathrm{VI})$ reduction in BESs.

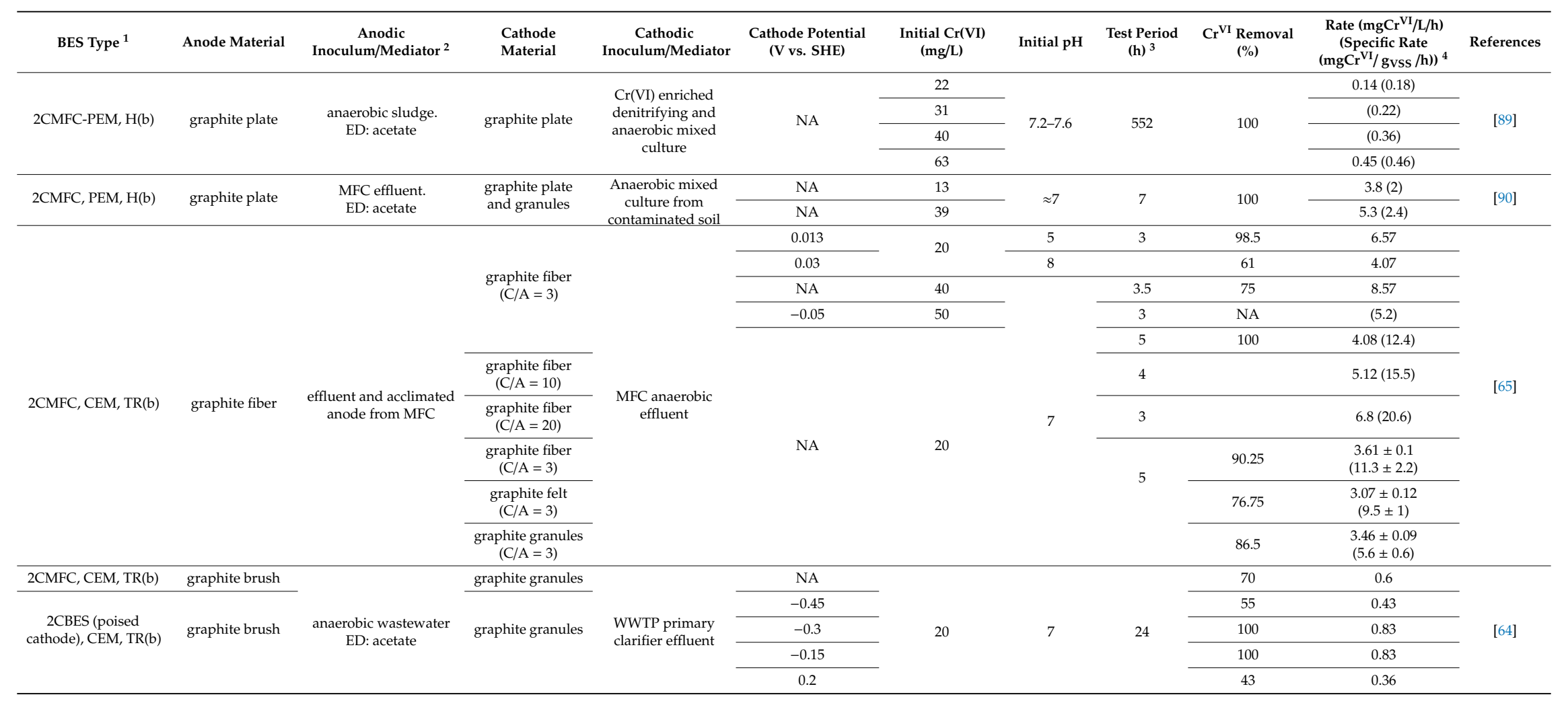


Table 2. Cont

\begin{tabular}{|c|c|c|c|c|c|c|c|c|c|c|c|}
\hline BES Type ${ }^{1}$ & Anode Material & $\begin{array}{c}\text { Anodic } \\
\text { Inoculum/Mediator }{ }^{2}\end{array}$ & $\begin{array}{l}\text { Cathode } \\
\text { Material }\end{array}$ & $\begin{array}{c}\text { Cathodic } \\
\text { Inoculum/Mediator }\end{array}$ & $\begin{array}{l}\text { Cathode Potential } \\
\text { [V vs. SHE] }\end{array}$ & $\begin{array}{c}\text { Initial Cr(VI) } \\
(\mathrm{mg} / \mathrm{L})\end{array}$ & Initial $\mathrm{pH}$ & $\begin{array}{l}\text { Test Period } \\
\text { (h) }{ }^{3}\end{array}$ & $\begin{array}{c}\mathrm{Cr}^{\mathrm{VI}} \text { Removal } \\
(\%)\end{array}$ & $\begin{array}{c}\text { Rate }(\mathrm{mgCr} V \mathrm{VI} / \mathrm{L} / \mathrm{h}) \\
(\mathrm{Specific} \mathrm{Rate} \\
\left.\left(\mathrm{mgCr}^{\mathrm{II}} / \mathrm{gvss} / \mathrm{h}\right)\right)^{4}\end{array}$ & References \\
\hline \multirow{5}{*}{ 2CMFC, CEM, H(sb) } & \multirow{5}{*}{$\begin{array}{c}\text { reticulated } \\
\text { vitreous carbon }\end{array}$} & \multirow{5}{*}{$\begin{array}{l}\text { Shewanella oneidensis } \\
\text { MR-1. ED: lactate }\end{array}$} & \multirow{5}{*}{$\begin{array}{c}\text { reticulated } \\
\text { vitreous carbon }\end{array}$} & $\begin{array}{c}\text { Shewanella } \\
\text { oneidensis MR1 }\end{array}$ & \multirow{5}{*}{ NA } & \multirow{5}{*}{2.5 ( 3 cycles) } & \multirow{5}{*}{7} & \multirow{5}{*}{$\begin{array}{c}72 \\
\text { (each cycle) }\end{array}$} & $60-100$ & $0.02-0.04$ & \multirow{5}{*}{ [91] } \\
\hline & & & & $\begin{array}{l}\text { Sherwanella } \\
\text { putrefaciens }\end{array}$ & & & & & $92-100$ & $0.03-0.04$ & \\
\hline & & & & $\begin{array}{c}\text { Shewanella } \\
\text { amazonensis }\end{array}$ & & & & & $72-100$ & $0.025-0.04$ & \\
\hline & & & & $\begin{array}{l}\text { Shewanella sp } \\
\text { ANA3 }\end{array}$ & & & & & $32-100$ & $0.01-0.04$ & \\
\hline & & & & Shewanella loihica & & & & & $44-100$ & $0.015-0.04$ & \\
\hline 2CMFC, PEM, H(b) & graphite felt & $\begin{array}{l}\text { S.oneidensis MR-1. } \\
\text { ED: lactate }\end{array}$ & graphite felt & $\begin{array}{c}\text { Shewanella } \\
\text { oneidensis MR-1 }\end{array}$ & \multirow{3}{*}{ NA } & \multirow{3}{*}{10 (6 cycles) } & \multirow{3}{*}{7} & \multirow{3}{*}{300} & 90 & $0.1-1.1$ & \multirow{4}{*}{ [92] } \\
\hline \multirow{3}{*}{$\begin{array}{c}\text { 2CBES (poised } \\
\text { cathode), PEM, H(b) }\end{array}$} & \multirow{3}{*}{ graphite felt } & \multirow{3}{*}{$\begin{array}{l}\text { Sherwanella oneidensis } \\
\text { MR-1. ED: lactate }\end{array}$} & \multirow{3}{*}{ graphite felt } & $\begin{array}{c}\text { Shewanella } \\
\text { oneidensis MR1 }\end{array}$ & & & & & 10 & 0.5 & \\
\hline & & & & $\begin{array}{c}\text { Sherwanella } \\
\text { oneidensis MR1; } \\
\text { MED: riboflavin }\end{array}$ & & & & & 13 & 0.65 & \\
\hline & & & & $\begin{array}{c}\text { Shewanella } \\
\text { oneidensis MR1; ED: } \\
\text { lactate }\end{array}$ & -0.3 & 20 & 7 & 4 & 45 & 2.25 & \\
\hline \multirow{2}{*}{ SCMFC (b) } & \multirow{2}{*}{ carbon brush } & \multirow{2}{*}{$\begin{array}{l}\text { municipal wastewater. } \\
\text { ED: acetate }\end{array}$} & \multirow{2}{*}{$\begin{array}{c}\text { carbon cloth with } \\
\text { Pt }\end{array}$} & \multirow{2}{*}{$\begin{array}{l}\text { municipal } \\
\text { wastewater; } \\
\text { ED: acetate }\end{array}$} & 2.93 & 1 & \multirow{2}{*}{6.5} & \multirow{2}{*}{120} & 89 & 0.01 & \multirow{2}{*}{ [93] } \\
\hline & & & & & 3.13 & 10 & & & 98.8 & 0.08 & \\
\hline \multirow[b]{2}{*}{ 2CMFC, CEM, TR(b) } & \multirow[b]{2}{*}{ graphite brush } & \multirow[b]{2}{*}{$\begin{array}{l}\text { MFC anodic effluent. } \\
\text { ED: acetate }\end{array}$} & \multirow[b]{2}{*}{ graphite felt } & \multirow[b]{2}{*}{$\begin{array}{c}\text { WWTP primary } \\
\text { clarifier effluent } \\
\text { acclimated to Cr(VI) } \\
\text { WWTP primary } \\
\text { clarifier effluent, } \\
\text { acclimated to } \\
\text { Cr(VI), Cu(II) and } \\
\text { Cd(II) }\end{array}$} & -0.074 & 5 & \multirow[b]{2}{*}{5.8} & \multirow[b]{2}{*}{4} & 100 & 1.21 & \\
\hline & & & & & NA & $\begin{array}{c}5(\text { with } \mathrm{Cu}(\mathrm{II}), \\
\mathrm{Cd}(\mathrm{II}))\end{array}$ & & & 100 & 0.49 & [94] \\
\hline 2CMFC, PEM, H(b) & graphite felt & Shewanella oneidensis & graphite felt & $\begin{array}{c}\text { Shewanella } \\
\text { oneidensis }\end{array}$ & NA & 10 (8 cycles) & 8 & 840 & $90-100$ & $0.9-1.95$ & [95] \\
\hline
\end{tabular}


Table 2. Cont.

\begin{tabular}{|c|c|c|c|c|c|c|c|c|c|c|c|}
\hline BES Type ${ }^{1}$ & Anode Material & $\begin{array}{c}\text { Anodic } \\
\text { Inoculum/Mediator }{ }^{2}\end{array}$ & $\begin{array}{l}\text { Cathode } \\
\text { Material }\end{array}$ & $\begin{array}{c}\text { Cathodic } \\
\text { Inoculum/Mediator }\end{array}$ & $\begin{array}{l}\text { Cathode Potential } \\
\text { [V vs. SHE] }\end{array}$ & $\begin{array}{c}\text { Initial Cr(VI) } \\
(\mathrm{mg} / \mathrm{L})\end{array}$ & Initial $\mathrm{pH}$ & $\begin{array}{l}\text { Test Period } \\
\text { (h) }{ }^{3}\end{array}$ & $\mathrm{Cr}^{\mathrm{VII}} \underset{(\%)}{(\%)}$ & $\begin{array}{c}\text { Rate }(\mathrm{mgCr} V \mathrm{VI} / \mathrm{L} / \mathrm{h}) \\
(\mathrm{Specific} \mathrm{Rate} \\
\left.\left(\mathrm{mgCr}^{\mathrm{II}} / \mathrm{gvss} / \mathrm{h}\right)\right)^{4}\end{array}$ & References \\
\hline \multirow[b]{2}{*}{ 2CMFC, PEM, C(b) } & \multirow[b]{2}{*}{ graphite felt } & \multirow[b]{2}{*}{$\begin{array}{l}\text { anaerobic sludge. } \\
\text { ED: glucose }\end{array}$} & \multirow[b]{2}{*}{ graphite felt } & $\begin{array}{l}\text { mixed culture from } \\
\text { MFC anode } \\
\text { (ex situ) }\end{array}$ & \multirow[b]{2}{*}{ NA } & \multirow[b]{2}{*}{20} & \multirow[b]{2}{*}{7} & \multirow[b]{2}{*}{24} & 79.3 & 0.66 & \multirow[b]{2}{*}[96]{} \\
\hline & & & & $\begin{array}{c}\text { anaerobic digester } \\
\text { sludge enriched in } \\
\text { presence of } \mathrm{Cr}(\mathrm{VI}) \\
\text { (in situ) }\end{array}$ & & & & & 20.2 & 0.17 & \\
\hline \multirow{5}{*}{ SCMEC, Cyl(c) } & \multirow{5}{*}{ carbon rod } & \multirow{5}{*}{ anaerobic sludge } & \multirow{5}{*}{ graphite felt } & \multirow{5}{*}{ anaerobic sludge } & \multirow{5}{*}{ NA } & 100 & & \multirow{5}{*}{$16 \mathrm{HRT}$} & $43.12-96.68$ & $2.69-6.04$ & \multirow{5}{*}{ [97] } \\
\hline & & & & & & $\begin{array}{c}100\left(200 \mathrm{NO}_{3}{ }^{-},\right. \\
100 \text { p-FNB) }\end{array}$ & & & 41.38 & 2.59 & \\
\hline & & & & & & $\begin{array}{c}100\left(200 \mathrm{NO}_{3}{ }^{-},\right. \\
150 \mathrm{p}-\mathrm{FNB})\end{array}$ & & & 49.14 & 3.07 & \\
\hline & & & & & & $\begin{array}{c}100\left(200 \mathrm{NO}_{3}^{-},\right. \\
200 \mathrm{p}-\mathrm{FNB})\end{array}$ & & & 55.21 & 3.45 & \\
\hline & & & & & & $\begin{array}{c}100\left(200 \mathrm{NO}_{3}{ }^{-},\right. \\
300 \text { p-FNB })\end{array}$ & & & 58.93 & 3.68 & \\
\hline \multirow{3}{*}{ 2CMFC-PEM, C(b) } & \multirow{3}{*}{ graphite felt } & \multirow{3}{*}{$\begin{array}{l}\text { anaerobic sludge. } \\
\text { ED: glucose }\end{array}$} & graphite felt & \multirow{3}{*}{$\begin{array}{c}\text { acclimated MFC } \\
\text { anode }\end{array}$} & NA & \multirow{3}{*}{20} & \multirow{3}{*}{7} & & 28.3 & $1.13 \pm 0.01$ & \multirow{3}{*}{ [98] } \\
\hline & & & $\begin{array}{c}\text { graphite felt } \\
/ \mathrm{NaX}\end{array}$ & & NA & & & 5 & 69 & $2.76 \pm 0.09$ & \\
\hline & & & $\begin{array}{l}\text { graphite felt } \\
/ \mathrm{NaX}-\mathrm{HNO}_{3}\end{array}$ & & NA & & & 3 & 100 & $10.39 \pm 0.28$ & \\
\hline 2CMFC-PEM, H(b) & graphite felt & $\begin{array}{l}\text { sewage sludge. } \\
\text { ED: glucose }\end{array}$ & $\begin{array}{l}\text { graphene-modified } \\
\text { felt }\end{array}$ & acclimated MFC & NA & 40 & 7 & 48 & 100 & 0.83 & [99] \\
\hline \multirow{2}{*}{ 2CMFC, CEM, Cyl(b) } & graphite felt & MFC anodic effluent. & graphite felt & Stenotrophomonas & -0.04 & 20 & 58 & 5 & $74-83$ & $2.96-3.32$ & \\
\hline & & ED: acetate & & $\begin{array}{l}\text { Sp., S. malatophilla, } \\
\text { Serratia marcescens, } \\
\text { Achromobacter }\end{array}$ & -0.05 & $\begin{array}{c}20 \\
(20 \mathrm{mg} / \mathrm{LCd}(\mathrm{II}))\end{array}$ & & & $63-71$ & $2.52-2.84$ & [100] \\
\hline & & & & xylosoxidans & & & 6 & & 58.96 & 0.88 & \\
\hline SCMEC, $\mathrm{Cyl}(\mathrm{c})$ & graphite rod & activated sludge & carbon felt & activated sludge & NA & $\left(20 \mathrm{mg} / \mathrm{L} \mathrm{NO}_{3}-\right)$ & 7 & $20 \mathrm{HRT}$ & 72.65 & 1.09 & [101] \\
\hline & & & & & & & 8 & & 65.08 & 0.98 & \\
\hline 2CMFC-CEM, H(b) & graphite felt & anaerobic sludge & graphite felt & Bacillus cereus & NA & 27 & 7 & 25 & 100 & 2.56 & [102] \\
\hline
\end{tabular}

Notes: ${ }^{1}$ 2CMFC: Double chamber Microbial Fuel Cell. 2CBES-poised cathode: potentiostatically controlled bio-electrochemical systems. SCMFC: Single-Chamber Microbial Fuel Cell. SCMEC: Single-Chamber Microbial Electrolysis Cell. 3CMDC: three-chamber Microbial Desalinization Cell. 3CMFC: three-chamber Microbial Fuel Cell (anode and double cathode). PEM: Proton Exchange Membrane. CEM: Cation Exchange Membrane. BPM: Bipolar membrane. $\mathrm{H}=\mathrm{H}$-type reactor. $\mathrm{Cyl}=\mathrm{Cylindrical}$ reactor. $\mathrm{C}=$ cubic chambers reactor. TR $=$ tubular reactor. $(\mathrm{b})=$ batch mode operation. $(\mathrm{sb})=$ semi-batch mode operation, i.e., continuous flow anode chamber and batch cathodic chamber. (c) continuous flow operation ${ }^{2} \mathrm{ED}$ :

Electron Donor. MED: mediator for chemical or biological activity. WWTP (Wastewater Treatment Plant). PPy (polypyrrole). AQS (9,10-anthraquinone-2-sulfonic acid sodium salt). AQDS (anthraquinone-2-sulfonate) ${ }^{3}$ HRT: Hydraulic Retention Time. ${ }^{4}$ Specific rate normalized by the mass of volatile suspended solids (VSS) in the cathode compartment. NA: no available information. 
These experiments evaluated $\mathrm{Cr}(\mathrm{VI})$ reduction under anaerobic conditions. So far, no literature report a reduction of $\mathrm{Cr}(\mathrm{VI})$ in open-air biocathodes. Oxygen is unquestionably the preferred final electron acceptor for microorganisms. However, possible advantages to $\mathrm{Cr}(\mathrm{VI})$-reducing bacteria with an aerobic cathode may exist. $\mathrm{Cr}(\mathrm{VI})$-reducing bacteria may be favored over other species in an environment with specific toxicity, even though tolerance to high $\mathrm{Cr}(\mathrm{VI})$ concentrations, up to $1 \mathrm{~g}$ $\mathrm{Cr}(\mathrm{VI}) / \mathrm{L}$ or even above, have often been documented [103].

The first test with $\mathrm{Cr}(\mathrm{VI})$ reducing biocathode was performed by Tandukar et al. [89], who inoculated the cathodic compartment of a 2CMFC (PEM membrane) with a mix of a denitrifying and methanogenic mixed culture, dosing bicarbonate as sole carbon source. Anaerobic mixed culture fed with acetate served as anode inoculum. With graphite plate electrodes and an external $1000 \Omega$ resistor, the authors reported power densities of $7.0 \mathrm{~mW} / \mathrm{m}^{2}$ and $55.5 \mathrm{~mW} / \mathrm{m}^{2}$ depending on initial $\mathrm{Cr}(\mathrm{VI})$ concentration (22 and $63 \mathrm{mg} / \mathrm{L}$, respectively). The maximum specific $\mathrm{Cr}(\mathrm{VI})$ reduction rate, about $0.46 \mathrm{mgCrVI} / \mathrm{g}_{\mathrm{VSS}} / \mathrm{h}$, was registered at a $63 \mathrm{mgCr}(\mathrm{VI}) / \mathrm{L}$ initial concentration. Analysis of the $\mathrm{Cr}(\mathrm{VI})$ reduction community by $16 \mathrm{~S}$ rRNA gene sequences showed a predominance of phylotypes related to Trichococcus pasteurii and P. aeruginosa. Even considering the small amount of substrate that can leak from the anode, even when an ion-exchange membrane is used [104], and organic carbon released in cell lysis, most $\mathrm{Cr}(\mathrm{VI})$ reduction was obtained with autotrophic conditions.

In a batch-fed $2 \mathrm{CMFC}$, the cathode is inoculated with a mixed microbial consortium from a $\mathrm{Cr}(\mathrm{VI})$ contaminated site and $39.2 \mathrm{mg} \mathrm{Cr}(\mathrm{VI}) / \mathrm{L}$. Huang et al. [90] observed a specific reduction rate of about $2.4 \mathrm{mgCrVI} / \mathrm{g}_{\mathrm{VsS}} / \mathrm{h}$, and $3.9 \mathrm{~W} / \mathrm{m}^{2}$ maximum power production at a current density of $11.1 \mathrm{~mA} / \mathrm{m}^{2}$.

Anaerobic pure cultures were also tested [91,92,102]. Hsu et al. [91] compared $\mathrm{Cr}(\mathrm{VI})$ reduction by six Shewanella strains at the cathode of MFCs in repeated cycles, observing initially the use of the electrode as the sole electron source in all tested strains. The variability in $\mathrm{Cr}(\mathrm{VI})$ reduction was associated with different mechanisms of chromium reduction, not identified, for each Shewanella strain evaluated, and other factors such as biofilm attachment to the electrode. Repeated $\mathrm{Cr}(\mathrm{VI})$ injections resulted in a general decrease in the MFCs performances and high residual $\mathrm{Cr}(\mathrm{VI})$ concentrations, which were explained with microorganisms' finite tolerance limit to $\mathrm{Cr}(\mathrm{VI})$ exposure and gradual fouling of the system by biological or reduced chromium species, which limit the active surface area of the cathode. Xafenias et al. [92] inoculated the cathode of an MFC and a MEC with S. oneidensis MR-1 fed with lactate. The combined use of the electrode and lactate as electron donors allowed bio-electrochemical and non-bio-electrochemical $\mathrm{Cr}(\mathrm{VI})$ reduction at the same time, even the contribution of the two different mechanisms to the overall process was not recognized. In Wu et al. [102], Bacillus sp. showed efficient $\mathrm{Cr}(\mathrm{VI})$-reducing ability in both heterotrophic and autotrophic environments. $\mathrm{The} \mathrm{Cr}(\mathrm{VI})$ removal rate reached $2.56 \mathrm{mg} / \mathrm{L} / \mathrm{h}$, which was 1.75 times higher than that of the MFC with the sterile control cathode.

\subsection{Effects of $\mathrm{pH}$ and $\mathrm{Cr}(\mathrm{VI})$ Concentration}

Extreme $\mathrm{pH}$ values (indicatively $\mathrm{pH}<5$ or $>8$ ) and/or high chromium concentrations, typically 10-100 mg/L, can inhibit microbial activity. Tandukar et al. [89] reported that initial Cr(VI) concentrations above $80 \mathrm{mg} / \mathrm{L}$ inhibited the reduction rates in a denitrifying community. Li et al. [93] observed $10 \mathrm{mg} \mathrm{Cr}(\mathrm{VI}) / \mathrm{L}$ to irreversibly inhibit microbial activity in a single chamber MFC inoculated with municipal wastewater. Below toxic levels, increased initial $\mathrm{Cr}(\mathrm{VI})$ concentration, and following thermodynamics, was associated with an improved specific chromium reduction rate and MFC's power production [90,93].

The $\mathrm{pH}$, with its effects on the surface properties of the cells, including cell surface hydrophobicity, net surface electrostatic charge, and biofilm structure, may also heavily affect complex biological and electrochemical reactions at the biocathode. Variation in $\mathrm{pH}$ may also affect enzymatic activity, and produced $\mathrm{Cr}$ (III) precipitation or bio-adsorption [105]. In Huang et al. [64,65], $50 \mathrm{mg} / \mathrm{L}$ initial $\mathrm{Cr}(\mathrm{VI})$ concentration inhibited the catalytic activity of electrochemical bacteria in the biocathode, whereas, at a $20 \mathrm{mg} / \mathrm{L} \mathrm{Cr}(\mathrm{VI})$ concentration, chromium reduction efficiencies increased $(+27.3 \%)$ and decreased $(-21 \%)$ in acidic $(\mathrm{pH}=5)$ and alkaline catholyte $(\mathrm{pH}=8)$, with respect to neutral $\mathrm{pH}$. A 0.22 cell net 
potential increase, from $0.54 \mathrm{~V}$ at a $\mathrm{pH}$ of 8.0 to $0.76 \mathrm{~V}$ at a $\mathrm{pH}$ of 5.0 , beyond the theoretical value of $0.177 \mathrm{~V}$ derived by Nernst's law, was associated with a $\mathrm{pH}$ decrease in the cathodic compartment, which actually indicates a positive response of microorganisms' activity associated with a $\mathrm{pH}$ decline [64]. Similar effects have been reported for denitrifying biocathodes [106]. Clearly, $\mathrm{pH}$ also affected the $\mathrm{Cr}$ (III) precipitation, with $9.3 \mathrm{mg} / \mathrm{L}$ dissolved $\mathrm{Cr}$ (III) at the end of the test at $\mathrm{pH} 5.0$, in comparison to $0.3 \mathrm{mg} / \mathrm{L}$ at a $\mathrm{pH}$ of 8.0 .

\subsection{Effects of Cathode Potential}

Tests with potentiostatically controlled cathodes pointed out an optimal potential range that typically exists for enhancing $\mathrm{Cr}(\mathrm{VI})$ reduction performances in biocathodes $[95,107]$. Theoretically, from Nernst's law, in MFC with a chromium-reducing cathode and acetate-oxidizing bioanode, the open-circuit voltage at $\mathrm{pH} 7.0$ and $25^{\circ} \mathrm{C}$ is about $0.68 \mathrm{~V}$, which results in about $0.4 \mathrm{~V}$ theoretical cathode potential [90].

Lower set cathode potentials would promote the $\mathrm{Cr}(\mathrm{VI})$ reduction process. Huang et al. [64] compared the behavior of a potentiostatically controlled BES (with cathode operated at 200, $-150,-300$, and $-450 \mathrm{mV}$ vs. SHE) to an MFC operating with $200 \Omega$ external load. Cathode at $-150 /-300 \mathrm{mV}$ set potential promoted fast start-up time (19 days compared to 26 days in the uncontrolled MFC or 28 days in $+200 \mathrm{mV}$ set cathode system) and $\mathrm{Cr}(\mathrm{VI})$ reduction, with almost complete removal of $20 \mathrm{mg} / \mathrm{L}$ in $24 \mathrm{~h}$, with respect to $43-70 \%$ with the other systems. Furthermore, $+200 \mathrm{mV}$ and $-450 \mathrm{mV}$ poised cathode limited bacterial growth, whereas -150 and $-300 \mathrm{mV}$ had beneficial effects. In all the tests, the reduction of $\mathrm{Cr}(\mathrm{VI})$ was attributed to microorganisms by directly accepting electrons from the electrode surface and transferring them to $\mathrm{Cr}(\mathrm{VI})$, as, even in the test, at the most negative potential, no production of hydrogen gas was observed. Optimal set potential can provide an appropriate selective pressure for adaptation of the microbial community in the system, which leads to enhancements of microbial electrochemical interaction with the cathode. The difference between $\mathrm{Cr}(\mathrm{VI})$ reduction potential and the cathode set potential represents the maximum energy to be gained by the cathodic microorganisms. Thus, the lower the set cathode potential is, the more energy microorganisms will potentially obtain. However, in case the cathode potential is set too low and goes beyond the self-regulation capability of microbial consortia, the energy gain by the cathodic microorganisms gets lost. Likely -150 and $-300 \mathrm{mV}$ set potentials allowed the biomass to gain more energy than when $200 \mathrm{mV}$ set the potential. Although, theoretically most favorable, $-450 \mathrm{mV}$ may have exceeded the self-regulation capability of the microbial consortia, with no positive effect on power generation and $\mathrm{Cr}(\mathrm{VI})$ reduction [64].

Xafenias et al. [92] demonstrated the positive impact on $\mathrm{Cr}(\mathrm{VI})$ reduction of riboflavin, which is a naturally produced mediator, in potentiostatically-controlled Shewanella oneidensis MR-1 biocathodes. Different configurations, with lactate supplied as electron donor in inoculated and abiotic systems, with or without riboflavin addiction, were tested. At $20 \mathrm{mg} / \mathrm{L}$ initial $\mathrm{Cr}(\mathrm{VI})$ concentration, in a $-300 \mathrm{mV}$ poised biocathode fed with lactate $(30 \mathrm{mM}$, or equivalently $2700 \mathrm{mg} / \mathrm{L})$, up to $45 \% \mathrm{Cr}(\mathrm{VI})$ reduction was observed in $4 \mathrm{~h}$ in comparison with $5 \% \mathrm{Cr}(\mathrm{VI})$ reduction in a biotic system with no lactate and $15 \%$ reduction in abiotic systems with lactate. In 2CMFC with $S$. oneidensis MR-1 fed with lactate in both anodic and cathodic compartments, $\mathrm{Cr}(\mathrm{VI})$ reduction at the cathode $(10 \mathrm{mgCr}(\mathrm{VI}) / \mathrm{L}$ initial concentration) was coupled with $32.5 \mathrm{~mA} / \mathrm{m}^{2}$ maximum current density production [92].

\subsection{Effects of Materials, Reactor Design, and Other Operational Parameters}

Huang et al. [90] identified, together with $\mathrm{Cr}(\mathrm{VI})$ concentration, high conductivity of the electrolyte, (i.e., improved ion transport between the biofilm and bulk phase), as a key factor for efficient $\mathrm{Cr}(\mathrm{VI})$ reduction and power production. Increased conductivity of the solution, from $1.5 \mathrm{mS} / \mathrm{cm}$ to $10.6 \mathrm{mS} / \mathrm{cm}$, increased the specific $\mathrm{Cr}(\mathrm{VI})$ reduction rate by about $25 \%$, from $2.4 \mathrm{mg} /\left(\mathrm{L} \mathrm{g}_{\mathrm{VSS}} \mathrm{h}\right)$ to about $3.0 \mathrm{mg} /(\mathrm{L}$ gvss h).

As to electrode materials, most experiences tested graphite or carbon-based electrodes. Huang et al. [90] tested graphite electrodes' specific surface, by covering the cathode with graphite granules, to 
promote bacterial attachment and electrical connection between bacteria and the electrode surface. In a tubular $2 \mathrm{CMFC}$, with a cathode to anode surface ratio $(\mathrm{C} / \mathrm{A})$ of 3 , at a $\mathrm{pH}$ of 7 , and $22{ }^{\circ} \mathrm{C}$, the graphite fiber biocathode showed a higher specific $\mathrm{Cr}(\mathrm{VI})$ reduction rate and power generation than either graphite felt and granular graphite ones [65]. Specific $\mathrm{Cr}(\mathrm{VI})$ reduction rates on the graphite fiber cathodes, 12.4-20.6 mg/ gVSS /h, were about 10-100 folds higher than the values reported for biocatalyzed carbon plate or graphite granule cathode in H-type MFCs with about the same Cr(VI) concentrations $[89,90]$.

These results underline the coordinated role of the cathode surface area and reactor architecture on the biocathode performance. In Wu et al. [108], NaX zeolite-modified graphite felts were used as electrodes (anode and cathode) in 2CMFCs. NaX zeolite proved to enhance the hydrophilicity of the graphite felt by facilitating bacterial adhesion and electrochemical reaction, and by decreasing mass transport resistances. Two different fabrication methods for the NaX zeolite-modified graphite felts were testedin which the first one was tested without any pre-treatment of the felt and the second one was tested with $\mathrm{HNO}_{3}$ pre-treatment. Both methods, especially the latter, resulted in excellent performance, with significant improvement in both electricity generation and $\mathrm{Cr}(\mathrm{VI})$ reduction rates, in comparison with graphite felts MFC. The $\mathrm{HNO}_{3}$ pre-process remarkably enhanced NaX loading mass on the graphite felt, by decreasing the organic residues on the graphite surface. NaX zeolite-modified graphite felts MFC at an initial Cr(VI) concentration of $20 \mathrm{mg} / \mathrm{L}$ resulted in more than $410 \mathrm{mV}$ maximum voltage, $29 \mathrm{~mW} / \mathrm{m}^{2}$ power density, and complete removal of $\mathrm{Cr}(\mathrm{VI})$ in $3 \mathrm{~h}$, with an 8.2 times faster rate than simple graphite felts MFC. Nanostructured graphene also reduced Cr(VI) [99]. The maximum power density in an MFC with graphene biocathode was 5.7 times higher than the one produced with graphite felt biocathode. Electricity production, in fact, increased from 28.6 to $164 \mathrm{~mW} / \mathrm{m}^{2}$. Furthermore, improved efficiency in $\mathrm{Cr}(\mathrm{VI})$ reduction was obtained, with $100 \%$ reduction in a $40 \mathrm{mgCr}(\mathrm{VI}) / \mathrm{L}$ solution within $48 \mathrm{~h}$, in comparison to only $58 \%$ reduction with graphite felt.

The most widely tested configuration with biocathodes is the 2CMFC. Even a study with a single-chamber reactor exists [93]. Organic substrate removal at the anode and cathodic chromium reduction were reflected in the open circuit potential of the system and $\mathrm{Cr}(\mathrm{III})$ deposition on the cathode, as revealed by scanning electron microscopy and energy-dispersive X-ray spectroscopy [93]. $\mathrm{Cr}(\mathrm{VI})$ conversion efficiencies ranged from $89 \%$ to $99 \%$ depending on initial $\mathrm{Cr}(\mathrm{VI})$ concentrations $(89 \%$ at $1.1 \mathrm{mg} / \mathrm{L}, 95 \%$ at $3 \mathrm{mg} / \mathrm{L}$, and $99 \%$ at $10 \mathrm{mg} / \mathrm{L})$. In the open-circuit control, $\mathrm{Cr}(\mathrm{VI})$ conversion efficiency was lower and decreased with $\mathrm{Cr}(\mathrm{VI})$ concentrations $(88 \%$ at $1.1 \mathrm{mg} / \mathrm{L}, 63 \%$ at $3 \mathrm{mg} / \mathrm{L}$, and $28 \%$ at $10 \mathrm{mg} / \mathrm{L}$ ). This means the SCMFC took advantage of electroactive bacteria using $\mathrm{Cr}(\mathrm{VI})$ as electron acceptor, as the other $\mathrm{Cr}(\mathrm{VI})$ reduction mechanisms, including bio-adsorption or bio-reduction by inelectroactive bacteria, as the open-circuit control pointed out, were inhibited at high $\mathrm{Cr}(\mathrm{VI})$ concentrations [93].

To increase microbial concentration and prevent premature cathode passivation due to $\mathrm{Cr}$ (III) precipitates during the system set-up, Wu et al. [96] proposed an ex situ acclimatization method for $\mathrm{Cr}(\mathrm{VI})$-reducing biocathodes. The electrode was initially enriched with exoelectrogenic biofilm as an MFC anode, and the system was subsequently established using the anode as biocathode. This method allowed for the development of a mature biofilm in a shorter period of acclimatization $(<19$ days in the authors' experience) compared to traditional in situ methods, with $\mathrm{Cr}(\mathrm{VI})$ removal reaching $79 \%$ in $24 \mathrm{~h}$, which is about four times higher than the one observed in the MFC with an in situ acclimated cathode. The improved performance was attributed not only to avoidance of premature formation of $\mathrm{Cr}$ (III) precipitates on the electrode, during biofilm acclimatization, but also to the enhanced bacterial growth rates in the heterotrophic anodic environment, which leads to high microbial density and bacterial coverage of the electrode. This may limit the effects of $\mathrm{Cr}(\mathrm{VI})$ toxicity on the microorganisms, at the anode/cathode inversion. 


\subsection{Simultaneous Reduction of $\mathrm{Cr}(\mathrm{VI})$ and Other Metals}

As abiotic cathodes, biocathodes are also being tested for the simultaneous reduction of multiple metals, usually present in a variety of metal-processing wastewaters. Huang et al. [94] demonstrated that bacterial communities in biocathodes could adaptively evolve to utilize solutions containing mixtures of metals. Reduction rates of $\mathrm{Cr}(\mathrm{VI}), \mathrm{Cu}(\mathrm{II})$, and $\mathrm{Cd}(\mathrm{III})$ in BESs with biocathodes individually acclimated to the three different metals or acclimated to increased concentrations of a mixture of metalswere compared. In a $\mathrm{Cr}(\mathrm{VI})$ acclimated biocathode, the $\mathrm{Cr}(\mathrm{VI})$ reduction rate decreased from about $1.21 \mathrm{mg} / \mathrm{L} / \mathrm{h}$ to $0.49 \mathrm{mg} / \mathrm{L} / \mathrm{h}$ in the presence of $5 \mathrm{mg} / \mathrm{L} \mathrm{Cu}(\mathrm{II})$ and $5 \mathrm{mg} / \mathrm{L} \mathrm{Cd}(\mathrm{II})$. Acclimatization, by gradually increasing concentrations of mixed metals, allowed complete removal of $\mathrm{Cr}(\mathrm{VI})$ at a rate similar to that originally obtained with the reactor acclimated to $\mathrm{Cr}(\mathrm{VI})$ only. Analysis of bacterial communities showed different communities on the biocathodes of the reactors acclimated to the mixed metal solutions, compared to reactors acclimated only to a single metal. The decrease in diversity of the microbial communities was likely due to the greater toxicity of the mixed metals compared to only single metals. At the phylum level, compared to $\mathrm{Cr}(\mathrm{VI})$ acclimated biofilm, the relative abundance of Proteobacteria, Actinobacteria, Firmicutes, and Tenericutes increased in biofilms acclimated to mixed metals. Synergistetes, to the contrary, were absent following acclimation to the mixed metals.

Huang et al. [100] examined $\mathrm{Cr}(\mathrm{VI})$ and $\mathrm{Cd}(\mathrm{II})$ reductions on biocathode in pure culture MFC experiments with known electrochemically active bacteria, Stenotrophomonas sp. YS1, Stenotrophomonas maltophilia YS2, Serratia marcescens YS3, and Achromobacter xylosoxidans YS8. Cr(VI) reduction in the MFCs decreased in the presence of Cd(II) for all the pure cultures, with removals in a 5-h period ranging from $63 \%$ to $71 \%$, depending on the species, compared to a range of $73-82 \%$ when $\mathrm{Cd}$ (II) was absent. $\mathrm{Cr}(\mathrm{VI})$ removal in biocathodes was higher than in the abiotic cathode, limited to about $39 \%$. $\mathrm{Cd}(\mathrm{II})$ removal, on the contrary, was not impacted by the presence of $\mathrm{Cr}(\mathrm{VI})$.

\section{4. $\mathrm{Cr}(\mathrm{VI})$ Reduction at Bioanode}

Yeon et al. [57] enriched electroactive $\mathrm{Cr}(\mathrm{VI})$-reducing bacteria in the anode compartment of MFC with the air cathode, using $\mathrm{Cr}(\mathrm{VI})$-containing sludge from a leather tanning wastewater treatment plant fed with synthetic wastewater. At the end of the enrichment procedure, $\mathrm{Cr}(\mathrm{VI})$ removal capability of such biofilm was observed with a $93 \%$ reduction of $5 \mathrm{mg} / \mathrm{L} \mathrm{Cr}(\mathrm{VI})$ and $61 \%$ of $25 \mathrm{mg} / \mathrm{L} \mathrm{Cr}(\mathrm{VI})$. MFC-mediated $\mathrm{Cr}(\mathrm{VI})$ removal was attributed to either physical adsorption on the carbon felt anode (about 20\%) and biological reactions including biosorption or reduction to $\mathrm{Cr}$ (III).

The bacterial community analysis by polymerase chain reaction-denaturing gradient gel electrophoresis (PCR-DGGE) of $16 \mathrm{~S}$ rDNA, after enrichment, pointed out the microbial consortium is composed of both $\mathrm{Cr}(\mathrm{VI})$ reducers with either electrochemical activity (such as Clostridium sp.) or not (like Acinetobacter sp.), and non-Cr(VI) reducers with/without electrochemical activity (as Actinobacteria $\mathrm{sp})$. Electroactive bacteria were responsible for electricity production in the MFC. However, reducers with electrochemical activity used $\mathrm{Cr}(\mathrm{VI})$ as an electron acceptor instead of interacting with the electrode, which causes a decrease in the current. $\mathrm{Cr}(\mathrm{VI})$ reduction was likely performed also by $\mathrm{Cr}(\mathrm{VI})$ reducers without electrochemical activity, with the required protons supplied by the metabolism of fermentative bacteria.

\section{Cr(VI) Bio-Electrochemical Remediation}

This review of published research, targeting treatment of $\mathrm{Cr}(\mathrm{VI})$ contaminated wastewater/industrial effluents, offers the first proof of concept for the chance of bio-electrochemical $\mathrm{Cr}(\mathrm{VI})$ remediation. Experiences with conventional bioreduction processes, under both aerobic and anaerobic conditions, by either pure cultures or mixed consortia, refer of $\mathrm{Cr}(\mathrm{VI})$ bioreduction rates in a $0.1-13.5 \mathrm{mg} / \mathrm{L} / \mathrm{h}$ range $[22,62,109-111]$, which are fully comparable to the values, $0.1-6.6 \mathrm{mg} / \mathrm{L} / \mathrm{h}$, observed in $\mathrm{Cr}(\mathrm{VI})$ reducing biocathodes. 
Therefore, with comparable results, bioelectrochemical $\mathrm{Cr}(\mathrm{VI})$ remediation over the conventional bioremediation presents the following advantages: (i) the chance of excluding any external chemical supply to support the microorganisms' actions, (ii) ease of monitoring and control of the process, and (iii) the potential recovery of reduced chromium deposited on the electrode.

It should be noted that all the reviewed studies were batch laboratory tests, under conditions quite different from natural $\mathrm{Cr}(\mathrm{VI})$ contaminated water/groundwater. It would, therefore, be useful to perform evaluations under dynamic water flow conditions as in contaminated aquifers, with real groundwater, as reported by Gregory and Lovley [49] for uranium-contaminated aquifers.

For groundwater remediation, it is important to take into consideration specific properties that potentially affect BES operation [20]. Although $\mathrm{Cr}(\mathrm{VI})$ contamination likely increases the specific conductivity, typical low specific conductivity value of groundwater (well below $2 \mathrm{mS} / \mathrm{cm}$ ) can be negatively impacted on BESs by implying higher ohmic and transport losses [30]. Moreover, $\mathrm{pH}$ shifts due to electrochemical $\mathrm{Cr}(\mathrm{VI})$ reduction in low buffering capacity systems may directly harm the electroactive bacteria and their removal performance [59]. Another challenge for bio-electrochemical treatment of contaminated groundwater is the presence, in addition to the contaminants, of a mixture of various naturally occurring inorganic (calcium, magnesium, carbonate, nitrates and sulphates, metals) and organic chemicals (e.g., humic acids) [112]. Magnesium and calcium can produce precipitates that could passivate the cathode with the consequent reduction of surface exchange active area [113]. Bio-electrochemical reduction has been recently reported for nitrate $[97,101,114]$ and sulphate [115]. So far, the study of co-contaminants with BESs is limited, but theoretically, since reduction potentials of nitrate and sulphate are similar to the reduction potential of several pollutants, they can be electron competitors in the remediation process and affect the microbial community at the biocathode [116]. Wang et al. [101] evaluated the simultaneous autotrophic denitrification and the reduction of $\mathrm{Cr}(\mathrm{VI})$ under different $\mathrm{pH}$ conditions $(6,7$, and 8$)$. The highest removal efficiencies for nitrates $(97 \%)$ and $\mathrm{Cr}(\mathrm{VI})(73 \%)$ were obtained at a $\mathrm{pH}$ of 7 . The stable combined reduction was mainly ascribed to Pseudomonas, Halomonas, and Thauera species.

Chen and colleagues [97] used a $3 \mathrm{~L}$ cylindrical single-chamber reactor with a graphite felt cathode and a central carbon rod anode. The reactor was filled with sulphur granules and inoculated with anaerobic sludge. The reactor was continuously fed with $100 \mathrm{mg} / \mathrm{L} \mathrm{Cr}(\mathrm{VI})$ synthetic wastewater with no organic $\mathrm{C}$ source ( $16 \mathrm{~h}$ of a hydraulic retention time) and run in the galvanostatic mode (current 10-60 mA). $\mathrm{Cr}(\mathrm{VI})$ reduction in the effluent ranged between $43 \%$ and $97 \%$, which is proportional to the externally supplied current. This observation, together with $\mathrm{SO}_{4}{ }^{2-}$ in the effluent, highlighted both sulphur and hydrogen autotrophic bacteria were responsible for $\mathrm{Cr}(\mathrm{VI})$ reduction by using the $\mathrm{S}$ granules in the reactor and $\mathrm{H}_{2}$ produced by the cathode as electron donors. A similar system, which is a single chamber cylindrical reactor operated in galvanostatic $(200 \mathrm{~mA})$ continuous flow mode $(20 \mathrm{~h}$ HRT), was adopted by Wang et al. [101] for removing $\mathrm{Cr}(\mathrm{VI})$ and nitrates from synthetic wastewater.

A continuous-flow BES was proposed for the simultaneous removal of $\mathrm{p}$-fluoronitrobenzene (p-FNB), nitrates, and hexavalent chromium from synthetic wastewater as well [97]. In this co-contaminated system, the competition for electrons, for the carbon source and metabolism of microorganisms negatively influenced the degradation rates in comparison with the single pollutant control tests. The biodegradation of p-FNB in the co-contaminated system produced an additional organic carbon source to the microorganisms that promoted $\mathrm{Cr}(\mathrm{VI})$ and nitrates removal (nitrate and $\mathrm{Cr}(\mathrm{VI})$ removal through degradation of $\mathrm{p}-\mathrm{FNB}$ ). Instead, the $\mathrm{p}$-FNB removal rate was controlled by electron availability (p-FNB degradation increased at currents above $40 \mathrm{~mA}$ ) [97].

It is also interesting to consider the full cycle of sulphur in BESs. The role of the sulphur cycle during the electro-bioremediation of oil spills has been recently reviewed [43]. Sulphide produced by sulphate reducers can be oxidized to elemental sulphur on the anode surface [117]. Elemental sulphur can be back oxidized to sulphate [118] or can be reduced again to sulphide [119]. The sulphur cycle in BESs can, thus, be effective in enhancing current production (i.e., via sulphide recycling) or in supplying electron acceptors for biodegradation of reduced pollutants, such as hydrocarbons (i.e., 
via back oxidation of sulphur to sulphate). In this context, it is crucial to understand the possible role of $\mathrm{Cr}(\mathrm{VI})$ in environments in which co-contamination occurs. Reduction of $\mathrm{Cr}$ (VI) to $\mathrm{Cr}$ (III) can represent a sink for sulphide oxidation, which affects the performance of the process. Whether the effect is positive or negative on the anodic oxidation is still an open question. During oxidation of BTEX (benzene, toluene, ethylbenzene, xylenes) mixtures in BESs where sulphate was present in the medium $(250 \mathrm{mg} / \mathrm{L})$, the bacterial communities enriched on the anodes were dominated by microorganisms linked to the sulphur cycle. However, bacteria able to oxidize hydrocarbons and to perform direct electron transfer to the electrode (i.e., Geobacter spp.) were also detected [120]. In similar conditions, the competition between the anode and chromium for the scavenging of sulphide could facilitate the enrichment on the electrode of microorganisms not directly linked to the sulphur cycle. No study of $\mathrm{Cr}(\mathrm{VI})$ bioelectrochemical remediation in the presence of nitrate and sulphate is available. However, interferences with chromium reduction are likely to occur. Therefore, further understanding of chemical species that coexist with the target pollutant in groundwater is required.

In view of in situ applications, the effects of soil particles on pollutant partitioning and bioavailability, as well as system conductance need to be assessed. Soil type and external resistance significantly affected the current and $\mathrm{Cr}(\mathrm{VI})$ removal efficiency in soil MFCs tests operated at external resistances of 100 and $1000 \Omega$ for 16 days [121]. The current production and $\operatorname{Cr}(\mathrm{VI})$ reduction in red soil and fluvo-aquic soil MFCs were compared. Red soil MFC performed better in the current production, but showed a lower $\mathrm{Cr}(\mathrm{VI})$ removal than fluvo-aquic soil MFC, which implies red soil may contain more electron acceptors that competed with the $\mathrm{Cr}(\mathrm{VI})$ reduction reaction [121]. About $60 \%$ to $90 \%$ of $\mathrm{Cr}(\mathrm{VI})$ was removed in 16 days of operation of a soil MFCs, while only $32-46 \%$ was removed in the open circuit control. Experiences integrating plants, microbes, and electrochemistry revealed promising applications of BESs to shallow contaminations [122,123], since plants can rely on atmospheric $\mathrm{CO}_{2}$ for photosynthesis and secrete root exudates that can serve as carbon sources and electron donors for microbes in the rhizosphere to promote biodegradation/biostabilization.

\section{Conclusions}

Ever since the discovery of microbial remediation methods for $\mathrm{Cr}(\mathrm{VI})$, many technological approaches have been developed, and some are already used in full-scale treatments. As compared to other energy-intensive technologies, bioremediation is considered a promising cost-efficient and sustainable option. Microbial electrochemical systems have been recently proposed as an alternative platform for bioremediation of $\mathrm{Cr}(\mathrm{VI})$ and other toxic chemicals. BESs, in comparison with other bioremediation techniques, are particularly appealing for in situ applications, since they do not require relevant chemical addition in the subsurface and may entail a low energy supply. Reducing energy costs and chemical soil amendments implies lower operating costs for the BESs, which is particularly valuable considering the typical timeframe required for groundwater remediation. Moreover, in the $\mathrm{Cr}(\mathrm{VI})$ contamination treatment, the deposition of $\mathrm{Cr}(\mathrm{III})$ onto the electrode may enable extraction and recovery of $\mathrm{Cr}(\mathrm{III})$.

In lab-scale studies, BESs were competent in reducing at the cathode $\mathrm{Cr}(\mathrm{VI})$ in contaminated water streams with initial concentrations as low as $1 \mathrm{mg} / \mathrm{L}$ up to about $1 \mathrm{~g} / \mathrm{L}$. Even though positive results have been reported with abiotic cathode systems, biocathodes offer several advantages in $\mathrm{Cr}(\mathrm{VI})$ reduction from the perspective of groundwater remediation, such as the effectiveness in the natural waters' $\mathrm{pH}$ range and the exploitation of microbial catalysis, which limits cathode passivation due to Cr(III) precipitation.

Nonetheless, much work is still needed to improve the $\mathrm{Cr}(\mathrm{VI})$ reduction rate at the biocathode to maximize the advantages of biocathode BESs over conventional biological processes. A lack in the long-term pilot and scale-up research suggests that more focus should be given to key factors that need to be considered for fully-practiced feasibility studies and full-scale applications. For example, the stability of processes and equipment and the area of influence that each BES module can effectively cover have to be addressed. In addition, flexible configurations to adapt to different 
site-specific characteristics (for example, water table depth, soil types, etc.) are required for in situ remediation. No preliminary models have been developed to start addressing this issue. Further research is needed to understand the mechanisms driving BES function and, thus, to fully exploit BES potential in real contaminated soil and groundwater. Many challenges, including the selection of microorganisms, cheap materials, and an optimal reactor configuration, need to be addressed during the technology scale-up.

Author Contributions: Conceptualization, G.B., A.F.M. and E.S.; literature review of microbial mechanisms of $\mathrm{Cr}(\mathrm{VI})$ reduction G.B., A.E.T. and M.D.; literature review of electrochemical and bio-cathodic $\mathrm{Cr}(\mathrm{VI})$ reduction, G.B., A.F.M. and E.S.; organization of the information, synthesis and critical analysis, G.B., A.E.T., A.F.M. and E.S.; writing - original draft preparation, A.F.M. and E.S.; writing—review and editing, G.B., A.E.T., M.D. and E.S.; project supervision, S.S. and A.F.

Funding: The Fondazione Cariplo in the framework of the project BEvERAGE-BioElEctrochemical RemediAtion of Groundwater plumes (2015-0195) supported this work.

Conflicts of Interest: The authors declare no conflict of interest.

\section{References}

1. Humphries, A.C.; Nott, K.P.; Hall, L.D.; Macaskie, L.E. Reduction of $\mathrm{Cr}(\mathrm{VI})$ by immobilized cells of desulfovibrio vulgaris NCIMB 8303 and Microbacterium sp. NCIMB 13776. Biotechnol. Bioeng. 2005, 90, 589-596. [CrossRef] [PubMed]

2. Marsh, T.L.; McInerney, M.J. Relationship of Hydrogen Bioavailability to Chromate Reduction in Aquifer Sediments. Appl. Environ. Microbiol. 2001, 67, 1517-1521. [CrossRef] [PubMed]

3. Palmer, C.D.; Puls, R.W.Natural Attenuation of Hexavalent Chromium in Ground Water and Soils; EPA/540/5-94/505; U.S. Environmental Protection Agency Ground Water Issue; Superfund Technology Support Center for Ground Water-Robert S. Kerr Environmental Research Laboratory: Ada, OK, USA, 1994; pp. 1-13.

4. Rai, D.; Eary, L.E.; Zachara, J.M. Environmental chemistry of chromium. Sci. Total Environ. 1989, 86, 15-23. [CrossRef]

5. Beverskog, B.; Puigdomenech, I. Revised Pourbaix diagrams for Chromium at 25-300 ${ }^{\circ}$ C. Corros. Sci. 1997, 39, 43-57. [CrossRef]

6. Zayed, A.M.; Terry, N. Chromium in the environment: Factors affecting biological remediation. Plant Soil 2003, 249, 139-156. [CrossRef]

7. Chirwa, E.M.; Molokwane, P.P.P. Biological Cr(VI) reduction: Microbial diversity, kinetics and biotechnological solutions to pollution. In Biodiversity; Sofo, A., Ed.; InTech: Rijeka, Croatia, 2011; pp. 75-100.

8. Jadhav, U.U.; Hocheng, H. A review of recovery of metals from industrial waste. J. Achiev. Mater. Manuf. Eng. 2012, 54, 159-167.

9. Independent Environmental Technical Evaluation Group. Chromium (VI) Handbook; Guertin, J., Jacobs, J.A., Avakian, C.P., Eds.; CRC Press: New York, NY, USA, 2005.

10. European Food Safety Authority. Scientific Opinion on the risks to public health related to the presence of chromium in food and drinking water. EFSA J. 2014, 12, 3595.

11. Malaviya, P.; Singh, A. Physicochemical Technologies for Remediation of Chromium-Containing Waters and Wastewaters. Crit. Rev. Environ. Sci. Technol. 2011, 41, 1111-1172. [CrossRef]

12. Jin, W.; Du, H.; Zheng, S.; Zhang, Y. Electrochemical processes for the environmental remediation of toxic $\mathrm{Cr}(\mathrm{VI})$ : A review. Electrochim. Acta 2015, 191, 1044-1055. [CrossRef]

13. Brungesh, K.; Nagabhushana, B.; Raveendra, R.; Krishna, K.; Prashantha, P.; Nagabhushana, H. Adsorption of $\mathrm{Cr}(\mathrm{VI})$ from Aqueous Solution onto a Mesoporous Carbonaceous Material Prepared from Naturally Occurring Pongamia pinnata Seeds. Environ. Anal. Toxicol. 2015, 5, 1.

14. Caputo, D.; De Gennaro, B.; Pansini, M.; Colella, C. Chromium removal from water by ion exchange using zeolites and solidification of the resulting sludge in a cement matrix. In Studies in Surface Science and Catalysis; Kiricsi, I., Nagy, J.B., Karge, H.G., Palyi, G., Eds.; Elsevier Science Publisher B.V.: Amsterdam, the Netherlands, 1999; Volume 125, pp. 723-730.

15. Rajeswari, V.; Janaki, V.; Shanthi, K.; Kamala-Kannan, S. Adsorption and subsequent detoxification of hexavalent chromium in aqueous solution using polypyrrole-bacterial extracellular polysaccharide nanocomposite. Environ. Prog. Sustain. Energy 2016, 35, 1293-1297. [CrossRef] 
16. Jeyasingh, J.; Philip, L. Bioremediation of chromium contaminated soil: Optimization of operating parameters under laboratory conditions. J. Hazard. Mater. 2005, 118, 113-120. [CrossRef] [PubMed]

17. Palmer, C.D.; Wittbrodt, P.R. Processes affecting the remediation of chromium-contaminated sites. Environ. Health Perspect. 1991, 92, 25-40. [CrossRef] [PubMed]

18. Tseng, J.K.; Bielefeldt, A.R. Low-Temperature Chromium(VI) Biotransformation in Soil with Varying Electron Acceptors. J. Environ. Qual. 2002, 31, 1831-1841. [CrossRef] [PubMed]

19. Turick, C.E.; Graves, C.; Apel, W.A. Bioremediation potential of $\mathrm{Cr}(\mathrm{VI})$-contaminated soil using indigenous microorganisms. Bioremediat. J. 1998, 2, 1-6. [CrossRef]

20. Pous, N.; Balaguer, M.D.; Colprim, J.; Puig, S. Opportunities for groundwater microbial electro-remediation. Microb. Biotechnol. 2018, 11, 119-135. [CrossRef] [PubMed]

21. Brodie, E.L.; Joyner, D.C.; Faybishenko, B.; Conrad, M.E.; Rios-Velazquez, C.; Malave, J.; Martinez, R.; Mork, B.; Willett, A.; Koenigsberg, S.; et al. Microbial community response to addition of polylactate compounds to stimulate hexavalent chromium reduction in groundwater. Chemosphere 2011, 85, 660-665. [CrossRef]

22. Somenahally, A.C.; Mosher, J.J.; Yuan, T.; Podar, M.; Phelps, T.J.; Brown, S.D.; Yang, Z.K.; Hazen, T.C.; Arkin, A.P.; Palumbo, A.V.; et al. Hexavalent chromium reduction under fermentative conditions with lactate stimulated native microbial communities. PLoS ONE 2013, 8, e83909. [CrossRef]

23. Deng, B.; Stone, A.T. Surface-Catalyzed Chromium(VI) Reduction: The $\mathrm{TiO}_{2}-\mathrm{CrVI}-$ Mandelic Acid System. Environ. Sci. Technol. 1996, 30, 463-472. [CrossRef]

24. Beretta, G.; Mastorgio, A.F.; Pedrali, L.; Saponaro, S.; Sezenna, E. Support tool for identifying in situ remediation technology for sites contaminated by hexavalent chromium. Water 2018, 10, 1344. [CrossRef]

25. Elangovan, R.; Philip, L.; Chandraraj, K. Hexavalent chromium reduction by free and immobilized cell-free extract of arthrobacter rhombi-RE. Appl. Biochem. Biotechnol. 2010, 160, 81-97. [CrossRef] [PubMed]

26. Yang, J.; He, M.; Wang, G. Removal of toxic chromate using free and immobilized Cr(VI)-reducing bacterial cells of intrasporangium sp. Q5-1. World J. Microbiol. Biotechnol. 2009, 25, 1579-1587. [CrossRef]

27. Liu, H.; Guo, L.; Liao, S.; Wang, G. Reutilization of immobilized fungus Rhizopus sp. LG04 to reduce toxic chromate. J. Appl. Microbiol. 2012, 112, 651-659. [CrossRef] [PubMed]

28. Butler, E.C.; Chen, L.; Hansel, C.M.; Krumholz, L.R.; Elwood Madden, A.S.; Lan, Y.; Madden, A.S.E.; Lan, Y. Biological versus mineralogical chromium reduction: Potential for reoxidation by manganese oxide. Environ. Sci. Process. Impacts 2015, 17, 1930-1940. [CrossRef] [PubMed]

29. Varadharajan, C.; Beller, H.R.; Bill, M.; Brodie, E.L.; Conrad, M.E.; Han, R.; Irwin, C.; Larsen, J.T.; Lim, H.C.; Molins, S.; et al. Reoxidation of Chromium(III) Products Formed under Different Biogeochemical Regimes. Environ. Sci. Technol. 2017, 51, 4918-4927. [CrossRef] [PubMed]

30. Logan, B.E.; Hamelers, B.; Rozendal, R.; Schröder, U.; Keller, J.; Freguia, S.; Aelterman, P.; Verstraete, W.; Rabaey, K. Microbial fuel cells: Methodology and technology. Environ. Sci. Technol. 2006, 40, 5181-5192. [CrossRef] [PubMed]

31. Shi, L.; Dong, H.; Reguera, G.; Beyenal, H.; Lu, A.; Liu, J.; Yu, H.-Q.Q.; Fredrickson, J.K. Extracellular electron transfer mechanisms between microorganisms and minerals. Nat. Rev. Microb. 2016, 14, 651-662. [CrossRef]

32. Rabaey, K.; Angenent, L.T.T.; Schröder, U.; Keller, J. Bioelectrochemical Systems: From Extracellular Electron Transfer to Biotechnological Application; IWA Publishing: London, UK, 2009.

33. Kokabian, B.; Gude, V.G. Role of membranes in bioelectrochemical systems. Membr. Water Treat. 2015, 6, 53-75. [CrossRef]

34. Gude, V.G.; Kokabian, B.; Gadhamshetty, V.G. Beneficial Bioelectrochemical Systems for Energy, Water, and Biomass Production. J. Microb. Biochem. Technol. 2013, S6:005, 1-14.

35. Santoro, C.; Arbizzani, C.; Erable, B.; Ieropoulos, I. Microbial fuel cells: From fundamentals to applications. A review. J. Power Sources 2017, 356, 225-244. [CrossRef]

36. Rabaey, K.; Rozendal, R.A. Microbial electrosynthesis-Revisiting the electrical route for microbial production. Nat. Rev. Microbiol. 2010, 8, 706-716. [CrossRef] [PubMed]

37. Pant, D.; Singh, A.; Van Bogaert, G.; Irving Olsen, S.; Singh Nigam, P.; Diels, L.; Vanbroekhoven, K. Bioelectrochemical systems (BES) for sustainable energy production and product recovery from organic wastes and industrial wastewaters. RSC Adv. 2012, 2, 1248-1263. [CrossRef]

38. Li, X.; Abu-Reesh, I.; He, Z. Development of Bioelectrochemical Systems to Promote Sustainable Agriculture. Agriculture 2015, 5, 367-388. [CrossRef] 
39. Nancharaiah, Y.V.; Venkata Mohan, S.; Lens, P.N.L. Metals removal and recovery in bioelectrochemical systems: A review. Bioresour. Technol. 2015, 195, 102-114. [CrossRef] [PubMed]

40. Lovley, D.R. Powering microbes with electricity: Direct electron transfer from electrodes to microbes. Environ. Microbiol. Rep. 2011, 3, 27-35. [CrossRef] [PubMed]

41. Wang, H.; Luo, H.; Fallgren, P.H.; Jin, S.; Ren, Z.J. Bioelectrochemical system platform for sustainable environmental remediation and energy generation. Biotechnol. Adv. 2015, 33, 317-334. [CrossRef]

42. Palma, E.; Daghio, M.; Franzetti, A.; Petrangeli Papini, M.; Aulenta, F. The bioelectric well: A novel approach for in situ treatment of hydrocarbon-contaminated groundwater. Microb. Biotechnol. 2018, 11, 112-118. [CrossRef]

43. Daghio, M.; Aulenta, F.; Vaiopoulou, E.; Franzetti, A.; Arends, J.B.A.; Sherry, A.; Suárez-Suárez, A.; Head, I.M.; Bestetti, G.; Rabaey, K. Electrobioremediation of oil spills. Water Res. 2017, 114, 351-370. [CrossRef]

44. Zhang, T.; Gannon, S.M.; Nevin, K.P.; Franks, A.E.; Lovley, D.R. Stimulating the anaerobic degradation of aromatic hydrocarbons in contaminated sediments by providing an electrode as the electron acceptor. Environ. Microbiol. 2010, 12, 1011-1020. [CrossRef]

45. Nguyen, V.K.; Park, Y.; Yu, J.; Lee, T. Simultaneous arsenite oxidation and nitrate reduction at the electrodes of bioelectrochemical systems. Environ. Sci. Pollut. Res. 2016, 23, 19978-19988. [CrossRef]

46. Lai, A.; Aulenta, F.; Mingazzini, M.; Palumbo, M.T.; Papini, M.P.; Verdini, R.; Majone, M. Bioelectrochemical approach for reductive and oxidative dechlorination of chlorinated aliphatic hydrocarbons (CAHs). Chemosphere 2017, 169, 351-360. [CrossRef] [PubMed]

47. Leitão, P.; Nouws, H.; Danko, A.S.; Aulenta, F. Bioelectrochemical Dechlorination of 1,2-DCA with an AQDS-Functionalized Cathode Serving as Electron Donor. Fuel Cells 2017, 17, 612-617. [CrossRef]

48. Cecconet, D.; Devecseri, M.; Callegari, A.; Capodaglio, A.G. Effects of process operating conditions on the autotrophic denitrification of nitrate-contaminated groundwater using bioelectrochemical systems. Sci. Total Environ. 2018, 613, 663-671. [CrossRef] [PubMed]

49. Gregory, K.B.; Lovley, D.R. Remediation and Recovery of Uranium from Contaminated Subsurface Environments with Electrodes. Environ. Sci. Technol. 2005, 39, 8943-8947. [CrossRef]

50. Harnisch, F.; Aulenta, F.; Schröder, U. Microbial Fuel Cells and Bioelectrochemical Systems: Industrial and Environmental Biotechnologies Based on Extracellular Electron Transfer. In Comprehensive Biotechnology, 2nd ed.; Moo-Young, M., Ed.; Academic Press: Burlington, NJ, USA, 2011; Volume 6, pp. 643-659.

51. Wang, H.; Ren, J.; Ren, Z.J.; Ren, J.; Ren, Z.J. Bioelectrochemical metal recovery from wastewater: A review. Water Res. 2014, 66, 219-232. [CrossRef]

52. Wu, Y.; Qi, H.; Gao, Y.; Wang, L. Heavy Metal Sensor Research Based on Microbial Fuel Cell. Int. J. Environ. Monit. Anal. 2018, 6, 53-64. [CrossRef]

53. Zhao, S.; Liu, P.; Niu, Y.; Chen, Z.; Khan, A.; Zhang, P.; Li, X. A Novel Early Warning System Based on a Sediment Microbial Fuel Cell for In Situ and Real Time Hexavalent Chromium Detection in Industrial Wastewater. Sensors 2018, 18, 642. [CrossRef]

54. Zhou, T.; Han, H.; Liu, P.; Xiong, J.; Tian, F.; Li, X. Microbial fuels cell-based biosensor for toxicity detection: A review. Sensors 2017, 17, 2230. [CrossRef]

55. Williams, K.H.; Nevin, K.P.; Franks, A.; Englert, A.; Long, P.E.; Lovley, D.R. Electrode-based approach for monitoring in situ microbial activity during subsurface bioremediation. Environ. Sci. Technol. 2010, 44, 47-54. [CrossRef]

56. Sophia, A.C.; Saikant, S. Reduction of chromium(VI) with energy recovery using microbial fuel cell technology. J. Water Process Eng. 2016, 11, 39-45. [CrossRef]

57. Yeon, R.E.; Kim, M.; Lee, S.J. Characterization of microbial fuel cells enriched using Cr(VI)-containing sludge. J. Microbiol. Biotechnol. 2011, 21, 187-191.

58. Clauwaert, P.; Aelterman, P.; Pham, T.H.; De Schamphelaire, L.; Carballa, M.; Rabaey, K.; Verstraete, W. Minimizing losses in bio-electrochemical systems: The road to applications. Appl. Microbiol. Biotechnol. 2008, 79, 901-913. [CrossRef] [PubMed]

59. Wang, G.; Huang, L.; Zhang, Y. Cathodic reduction of hexavalent chromium [Cr(VI)] coupled with electricity generation in microbial fuel cells. Biotechnol. Lett. 2008, 30, 1959-1966. [CrossRef] [PubMed]

60. Richard, F.C.; Bourg, A.C.M. Aqueous geochemistry of chromium: A review. Water Res. 1991, 25, 807-816. [CrossRef] 
61. Sophia, A.C.; Sai, S. Modified microbial fuel cell for $\mathrm{Cr}(\mathrm{VI})$ reduction and simultaneous bio-electricity production. J. Environ. Chem. Eng. 2016, 4, 2402-2409. [CrossRef]

62. Molokwane, P.E.; Meli, K.C.; Nkhalambayausi-Chirwa, E.M. Chromium (VI) reduction in activated sludge bacteria exposed to high chromium loading: Brits culture (South Africa). Water Res. 2008, 42, 4538-4548. [CrossRef]

63. Li, M.; Zhou, S.; Xu, Y.; Liu, Z.; Ma, F.; Zhi, L.; Zhou, X. Simultaneous Cr(VI) reduction and bioelectricity generation in a dual chamber microbial fuel cell. Chem. Eng. J. 2018, 334, 1621-1629. [CrossRef]

64. Huang, L.; Chai, X.; Chen, G.; Logan, B.E. Effect of set potential on hexavalent chromium reduction and electricity generation from biocathode microbial fuel cells. Environ. Sci. Technol. 2011, 45, 5025-5031. [CrossRef]

65. Huang, L.; Chai, X.; Cheng, S.; Chen, G. Evaluation of carbon-based materials in tubular biocathode microbial fuel cells in terms of hexavalent chromium reduction and electricity generation. Chem. Eng. J. 2011, 166, 652-661. [CrossRef]

66. Thatoi, H.; Das, S.; Mishra, J.; Rath, B.P.; Das, N. Bacterial chromate reductase, a potential enzyme for bioremediation of hexavalent chromium: A review. J. Environ. Manag. 2014, 146, 383-399. [CrossRef]

67. Viti, C.; Marchi, E.; Decorosi, F.; Giovannetti, L. Molecular mechanisms of Cr(VI) resistance in bacteria and fungi. FEMS Microbiol. Rev. 2014, 38, 633-659. [CrossRef] [PubMed]

68. Horitsu, H.; Futo, S.; Miyazawa, Y.; Ogai, S.; Kawai, K. Enzymatic reduction of hexavalent chromium by hexavalent chromium tolerant Pseudomonas ambigua G-1. Agric. Biol. Chem. 1987, 51, 2417-2420. [CrossRef]

69. Ackerley, D.F.; Gonzalez, C.F.; Park, C.H.; Ii, R.B.; Matin, A.; Keyhan, M. Chromate-Reducing Properties of Soluble Flavoproteins from Pseudomonas putida and Escherichia coli. Am. Soc. Microbiol. 2004, 70, 873-882. [CrossRef] [PubMed]

70. Cheung, K.H.; Gu, J.D. Mechanism of hexavalent chromium detoxification by microorganisms and bioremediation application potential: A review. Int. Biodeterior. Biodegrad. 2007, 59, 8-15. [CrossRef]

71. Camargo, F.A.O.; Bento, F.M.; Okeke, B.C.; Frankenberger, W.T. Hexavalent chromium reduction by an actinomycete, Arthrobacter crystallopoietes ES 32. Biol. Trace Elem. Res. 2004, 97, 183-194. [CrossRef]

72. Tahri Joutey, N.; Bahafid, W.; Sayel, H.; Ananou, S.; El Ghachtouli, N. Hexavalent chromium removal by a novel Serratia proteamaculans isolated from the bank of Sebou River (Morocco). Environ. Sci. Pollut. Res. 2014, 21, 3060-3072. [CrossRef]

73. Ishibashi, Y.; Cervantes, C.; Silver, S. Chromium reduction in Pseudomonas putida. Appl. Environ. Microbiol. 1990, 56, 2268-2270.

74. Mohapatra, R.K.; Parhi, P.K.; Thatoi, H.; Panda, C.R. Bioreduction of hexavalent chromium by Exiguobacterium indicum strain MW1 isolated from marine water of Paradip Port, Odisha, India. Chem. Ecol. 2017, 33, 114-130. [CrossRef]

75. Lovley, D.R.; Phillips, E.J.P. Reduction of Chromate by Desulfovibrio-Vulgaris and Its c3 Cytochrome. Appl. Environ. Microbiol. 1994, 60, 726-728.

76. Barrera-Díaz, C.E.; Lugo-Lugo, V.; Bilyeu, B. A review of chemical, electrochemical and biological methods for aqueous $\mathrm{Cr}(\mathrm{VI})$ reduction. J. Hazard. Mater. 2012, 223, 1-12. [CrossRef]

77. Wang, P.C.; Mori, T.; Komori, K.; Sasatsu, M.; Toda, K.; Ohtake, H. Isolation and characterization of an Enterobacter cloacae strain that reduces hexavalent chromium under anaerobic conditions. Appl. Environ. Microbiol. 1989, 55, 1665-1669.

78. Bencheikh-Latmani, R. Global transcriptional profiling of Shewanella oneidensis MR-1 during Cr (VI) and U (VI) reduction. Appl. Environ. Microbiol. 2005, 71, 7453-7460. [CrossRef]

79. Belchik, S.M.; Kennedy, D.W.; Dohnalkova, A.C.; Wang, Y.; Sevinc, P.C.; Wu, H.; Lin, Y.; Lu, H.P.; Fredrickson, J.K.; Shi, L. Extracellular reduction of hexavalent chromium by cytochromes MtrC and OmcA of Shewanella oneidensis MR-1. Appl. Environ. Microbiol. 2011, 77, 4035-4041. [CrossRef]

80. Němeček, J.; Pokorný, P.; Lhotský, O.; Knytl, V.; Najmanová, P.; Steinová, J.; Černík, M.; Filipová, A.; Filip, J.; Cajthaml, T. Combined nano-biotechnology for in-situ remediation of mixed contamination of groundwater by hexavalent chromium and chlorinated solvents. Sci. Total Environ. 2016, 563, 822-834. [CrossRef]

81. Jørgensen, B.B. Mineralization of organic matter in the sea bed-The role of sulphate reduction. Nature 1982, 296, 643-645. [CrossRef]

82. Inglett, K.S.; Bae, H.S.; Aldrich, H.C.; Hatfield, K.; Ogram, A.V. Clostridium chromiireducens sp. nov., isolated from Cr(VI)-contaminated soil. Int. J. Syst. Evol. Microbiol. 2011, 61, 2626-2631. [CrossRef] 
83. Battaglia-Brunet, F.; Foucher, S.; Denamur, A.; Ignatiadis, I.; Michel, C.; Morin, D. Reduction of chromate by fixed films of sulfate-reducing bacteria using hydrogen as an electron source. J. Ind. Microbiol. Biotechnol. 2002, 28, 154-159. [CrossRef]

84. Chung, J.; Nerenberg, R.; Rittmann, B.E. Bio-reduction of soluble chromate using a hydrogen-based membrane biofilm reactor. Water Res. 2006, 40, 1634-1642. [CrossRef]

85. McLean, J.S.; Beveridge, T.J.; Phipps, D. Isolation and characterization of a chromium-reducing bacterium from a chromated copper arsenate-contaminated site. Environ. Microbiol. 2000, 2, 611-619. [CrossRef]

86. Mclean, J.; Beveridge, T.J. Chromate Reduction by a Pseudomonad Isolated from a Site Contaminated with Chromated Copper Arsenate. Appl. Environ. Microbiol. 2001, 67, 1076-1084. [CrossRef]

87. Kracke, F.; Vassilev, I.; Krömer, J.O. Microbial Electron Transport and Energy Conservation-The Foundation for Optimizing Bioelectrochemical Systems. Front. Microbiol. 2015, 6, 575. [CrossRef]

88. Cordas, C.M.; Guerra, L.T.; Xavier, C.; Moura, J.J.G. Electroactive biofilms of sulphate reducing bacteria. Electrochim. Acta 2008, 54, 29-34. [CrossRef]

89. Tandukar, M.; Huber, S.J.; Onodera, T.; Pavlostathis, S.G. Biological chromium(VI) reduction in the cathode of a microbial fuel cell. Environ. Sci. Technol. 2009, 43, 8159-8165. [CrossRef]

90. Huang, L.; Chen, J.; Quan, X.; Yang, F. Enhancement of hexavalent chromium reduction and electricity production from a biocathode microbial fuel cell. Bioprocess Biosyst. Eng. 2010, 33, 937-945. [CrossRef]

91. Hsu, L.; Masuda, S.A.; Nealson, K.H.; Pirbazari, M. Evaluation of microbial fuel cell Shewanella biocathodes for treatment of chromate contamination. RSC Adv. 2012, 2, 5844-5855. [CrossRef]

92. Xafenias, N.; Zhang, Y.; Banks, C.J. Enhanced performance of hexavalent chromium reducing cathodes in the presence of Shewanella oneidensis MR-1 and lactate. Environ. Sci. Technol. 2013, 47, 4512-4520. [CrossRef]

93. Li, Y.; Wu, Y.; Puranik, S.; Lei, Y.; Vadas, T.; Li, B. Metals as electron acceptors in single-chamber microbial fuel cells. J. Power Sources 2014, 269, 430-439. [CrossRef]

94. Huang, L.; Wang, Q.; Jiang, L.; Zhou, P.; Quan, X.; Logan, B.E. Adaptively Evolving Bacterial Communities for Complete and Selective Reduction of $\mathrm{Cr}(\mathrm{VI}), \mathrm{Cu}(\mathrm{II})$, and $\mathrm{Cd}(\mathrm{II})$ in Biocathode Bioelectrochemical Systems. Environ. Sci. Technol. 2015, 49, 9914-9924. [CrossRef]

95. Xafenias, N.; Zhang, Y.; Banks, C.J. Evaluating hexavalent chromium reduction and electricity production in microbial fuel cells with alkaline cathodes. Int. J. Environ. Sci. Technol. 2015, 12, 2435-2446. [CrossRef]

96. Wu, X.; Zhu, X.; Song, T.; Zhang, L.; Jia, H.; Wei, P. Effect of acclimatization on hexavalent chromium reduction in a biocathode microbial fuel cell. Bioresour. Technol. 2015, 180, 185-191. [CrossRef]

97. Chen, D.; Wang, H.; Yang, K. Effective biodegradation of nitrate, $\mathrm{Cr}(\mathrm{VI})$ and p-fluoronitrobenzene by a novel three dimensional bioelectrochemical system. Bioresour. Technol. 2016, 203, 370-373. [CrossRef]

98. Wu, X.; Tong, F.; Yong, X.; Zhou, J.; Zhang, L.; Jia, H.; Wei, P. Effect of NaX zeolite-modified graphite felts on hexavalent chromium removal in biocathode microbial fuel cells. J. Hazard. Mater. 2016, 308, 303-311. [CrossRef]

99. Song, T.; Jin, Y.; Bao, J.; Kang, D.; Xie, J. Graphene/biofilm composites for enhancement of hexavalent chromium reduction and electricity production in a biocathode microbial fuel cell. J. Hazard. Mater. 2016, 317, 73-80. [CrossRef]

100. Huang, L.; Zhou, P.; Quan, X.; Logan, B.E. Removal of binary Cr(VI) and Cd(II) from the catholyte of MFCs and determining their fate in EAB using fluorescence probes. Bioelectrochemistry 2018, 122, 61-68. [CrossRef]

101. Wang, H.; Zhang, S.; Wang, J.; Song, Q.; Zhang, W.; He, Q.; Song, J.; Ma, F. Comparison of performance and microbial communities in a bioelectrochemical system for simultaneous denitrification and chromium removal: Effects of pH. Process Biochem. 2018, 73, 154-161. [CrossRef]

102. Wu, X.; Ren, X.; Owens, G.; Brunetti, G.; Zhou, J.; Yong, X.; Wei, P.; Jia, H. A Facultative Electroactive Chromium(VI)-Reducing Bacterium Aerobically Isolated From a Biocathode Microbial Fuel Cell. Front. Microbiol. 2018, 9, 2883. [CrossRef]

103. Sagar, S.; Dwivedi, A.; Yadav, S.; Tripathi, M.; Kaistha, S.D. Hexavalent chromium reduction and plant growth promotion by Staphylococcus arlettae Strain Cr11. Chemosphere 2012, 86, 847-852. [CrossRef]

104. Jung, R.K.; Cheng, S.; Oh, S.E.; Logan, B.E. Power generation using different cation, anion, and ultrafiltration membranes in microbial fuel cells. Environ. Sci. Technol. 2007, 41, 1004-1009.

105. Malaviya, P.; Singh, A. Bioremediation of chromium solutions and chromium containing wastewaters. Crit. Rev. Microbiol. 2016, 42, 607-633. [CrossRef] 
106. Clauwaert, P.; Desloover, J.; Shea, C.; Nerenberg, R.; Boon, N.; Verstraete, W. Enhanced nitrogen removal in bio-electrochemical systems by $\mathrm{pH}$ control. Biotechnol. Lett. 2009, 31, 1537-1543. [CrossRef]

107. Liang, P.; Fan, M.; Cao, X.; Huang, X. Evaluation of applied cathode potential to enhance biocathode in microbial fuel cells. J. Chem. Technol. Biotechnol. 2009, 84, 794-799. [CrossRef]

108. Wu, J.; Zhang, J.; Xiao, C. Focus on factors affecting $\mathrm{pH}$, flow of $\mathrm{Cr}$ and transformation between $\mathrm{Cr}(\mathrm{VI})$ and $\mathrm{Cr}(\mathrm{III})$ in the soil with different electrolytes. Electrochim. Acta 2016, 211, 652-662. [CrossRef]

109. Chai, L.; Huang, S.; Yang, Z.; Peng, B.; Huang, Y.; Chen, Y. Cr(VI) remediation by indigenous bacteria in soils contaminated by chromium-containing slag. J. Hazard. Mater. 2009, 167, 516-522. [CrossRef]

110. Kavita, B.; Keharia, H. Reduction of hexavalent chromium by Ochrobactrum intermedium BCR400 isolated from a chromium-contaminated soil. 3 Biotech 2012, 2, 79-87. [CrossRef]

111. Sharma, S.; Adholeya, A. Hexavalent chromium reduction in tannery effluent by bacterial species isolated from tannery effluent contaminated soil. J. Environ. Sci. Technol. 2012, 5, 142-154. [CrossRef]

112. Squillace, P.J.; Scott, J.C.; Moran, M.J.; Nolan, B.T.; Kolpin, D.W. VOCs, pesticides, nitrate, and their mixtures in groundwater used for drinking water in the United States. Environ. Sci. Technol. 2002, 36, 1923-1930. [CrossRef]

113. Santini, M.; Marzorati, S.; Fest-Santini, S.; Trasatti, S.; Cristiani, P. Carbonate scale deactivating the biocathode in a microbial fuel cell. J. Power Sources 2017, 356, 400-407. [CrossRef]

114. Duca, M.; Koper, M.T.M. Powering denitrification: The perspectives of electrocatalytic nitrate reduction. Energy Environ. Sci. 2012, 5, 9726. [CrossRef]

115. Coma, M.; Puig, S.; Pous, N.; Balaguer, M.D.; Colprim, J. Biocatalysed sulphate removal in a BES cathode. Bioresour. Technol. 2013, 130, 218-223. [CrossRef]

116. Bardiya, N.; Bae, J.H. Dissimilatory perchlorate reduction: A review. Microbiol. Res. 2011, 166, $237-254$. [CrossRef]

117. Daghio, M.; Vaiopoulou, E.; Patil, S.A.; Suárez-Suárez, A.; Head, I.M.; Franzetti, A.; Rabaey, K. Anodes stimulate anaerobic toluene degradation via sulfur cycling in marine sediments. Appl. Environ. Microbiol. 2016, 82, 297-307. [CrossRef]

118. Zhang, T.; Bain, T.S.; Barlett, M.A.; Dar, S.A.; Snoeyenbos-West, O.L.; Nevin, K.P.; Lovley, D.R. Sulfur oxidation to sulfate coupled with electron transfer to electrodes by Desulfuromonas strain TZ1. Microbiology 2014, 160, 123-129. [CrossRef]

119. Dutta, P.K.; Keller, J.; Yuan, Z.; Rozendal, R.A.; Rabaey, K. Role of sulfur during acetate oxidation in biological anodes. Environ. Sci. Technol. 2009, 43, 3839-3845. [CrossRef]

120. Daghio, M.; Espinoza Tofalos, A.; Leoni, B.; Cristiani, P.; Papacchini, M.; Jalilnejad, E.; Bestetti, G.; Franzetti, A. Bioelectrochemical BTEX removal at different voltages: Assessment of the degradation and characterization of the microbial communities. J. Hazard. Mater. 2018, 341, 120-127. [CrossRef]

121. Wang, C.; Deng, H.; Zhao, F. The Remediation of Chromium (VI)-Contaminated Soils Using Microbial Fuel Cells. Soil Sediment Contam. 2016, 25, 1-12. [CrossRef]

122. Habibul, N.; Hu, Y.; Wang, Y.K.; Chen, W.; Yu, H.Q.; Sheng, G.P. Bioelectrochemical Chromium(VI) Removal in Plant-Microbial Fuel Cells. Environ. Sci. Technol. 2016, 50, 3882-3889. [CrossRef]

123. Guan, C.Y.; Hu, A.; Yu, C.P. Stratified chemical and microbial characteristics between anode and cathode after long-term operation of plant microbial fuel cells for remediation of metal contaminated soils. Sci. Total Environ. 2019, 670, 585-594. [CrossRef]

(C) 2019 by the authors. Licensee MDPI, Basel, Switzerland. This article is an open access article distributed under the terms and conditions of the Creative Commons Attribution (CC BY) license (http://creativecommons.org/licenses/by/4.0/). 